Review

\title{
Mycotoxins: Producing Fungi and Mechanisms of Phytotoxicity
}

\section{Ahmed A. Ismaiel ${ }^{1, *}$ and Jutta Papenbrock ${ }^{2}$}

1 Department of Botany and Microbiology, Faculty of Science, Zagazig University, Zagazig 44519, Egypt

2 Institut für Botanik, Leibniz Universität Hannover, Herrenhäuser Straße 2, Hannover D-30419, Germany; E-Mail: jutta.papenbrock@botanik.uni-hannover.de

* Author to whom correspondence should be addressed; E-Mail: microbiologist_80@yahoo.com; Tel.: +2-012-2711-2912; Fax: +2-055-230-8213.

Academic Editor: Anna Andolfi

Received: 19 May 2015 / Accepted: 16 July 2015 / Published: 23 July 2015

\begin{abstract}
Mycotoxins are secondary fungal metabolites, toxic to humans, animals and plants. Among the hundreds of known mycotoxins, aflatoxins, citrinin, patulin, penicillic acid, tenuazonic acid, ochratoxin $\mathrm{A}$, cytochalasins, deoxynivalenol, fumonisins, fusarin $\mathrm{C}$, fusaric acid, and zearalenone are considered the types that most contaminate cereal grain. The majority of the mycotoxins in these groups are produced by three fungal genera: Aspergillus, Penicillium and Fusarium. These metabolites primarily affect the seed quality, germination, viability, seedling vigour, growth of root and cleoptile. Additionally, since the fungi responsible for the production of these mycotoxins are often endophytes that infect and colonize living plant tissues, accumulation of mycotoxins in the plant tissues may at times be associated with development of plant disease symptoms. The presence of mycotoxins, even in the absence of disease symptoms, may still have subtle biological effects on the physiology of plants. Several studies highlight the toxic effects of mycotoxins on animals and cell lines but little is known about the mode of action of most of these metabolites on plant cells. The most important mycotoxins with phytotoxic effects and their producers in addition to their discovery are briefly outlined below and will be addressed in this article.
\end{abstract}

Keywords: mycotoxins; producing fungi; phytotoxicity 


\section{Introduction}

The term mycotoxin was first used in the 1960s to describe the toxin associated with contaminated peanuts in animal feed and the loss of turkeys in England (Turkey-X-disease). This mycotoxin was later identified as the Aspergillus flavus toxin aflatoxin B1. Bennett [1] defined mycotoxins as "natural products produced by fungi that evoke a toxic response when introduced in low concentrations to higher vertebrates and other animals by a natural route". Mycotoxins are secondary metabolites, defined by Bennett and Bentley [2] as "metabolic intermediates or products, found as a differentiation product in restricted taxonomic groups, not essential to growth and life of the producing organism, and biosynthesized from one or more general metabolites by a wider variety of pathways than is available in general metabolism". The term was later applied to other toxic fungal natural products [3].

Traditionally, toxigenic fungi contaminating agricultural grains have been conventionally divided into two groups those invade seed crops have been described as "field" fungi (e.g., Cladosporium, Fusarium, Alternaria spp.), which reputedly gain access to seeds during plant development, and "storage" fungi, (e.g., Aspergillus; Penicillium spp.), which proliferate during storage [4]. Currently, this division is not so strict because according to Miller [5] four types of toxigenic fungi can be distinguished: (1) Plant pathogens as Fusarium graminearum and Alternaria alternata; (2) Fungi that grow and produce mycotoxins on senescent or stressed plants, e.g., F. moniliforme and Aspergillus flavus; (3) Fungi that initially colonize the plant and increase the feedstock's susceptibility to contamination after harvesting, e.g., A. flavus; (4) Fungi that are found on the soil or decaying plant material that occur on the developing kernels in the field and later proliferate in storage if conditions permit, e.g., P. verrucosum and A. ochraceus.

The involvement of Aspergillus spp. as plant pathogens has been reported and aflatoxin-infected crops have from time to time been returned to agricultural soils. This practice may prove hazardous, since both A. flavus and A. parasiticus can infect crops prior to harvesting [6]. The phytotoxic effects of the aflatoxins have been investigated, with respect to seed germination, and the inhibition of root and hypocotyl elongation [7,8]. Aflatoxin has been reported to occur within apparently healthy, intact seeds which suggest that the toxin can he transported from contaminated soil to the fruit [9]. Aflatoxin B1 (AFB1) can be translocated from the roots to the stems and leaves. If the soil microorganisms do not rapidly degrade the aflatoxin contained within the plowed under stover and grains, the possibility that the roots of the seedlings of the following year's crop will both absorb and translocate the aflatoxins to both the stems and leaves exists [10]. This could be hazardous to the plant's growth and development as well as to the consumer's health.

The Penicillium genus dominated the fungal flora, with mycotoxigenic species such as P. crustosum, $P$. chrysogenum, $P$. hirsutum, $P$. expansum, $P$. roqueforti, $P$. viridicatum, $P$. commune, $P$. aurantiogriseum, $P$. citrinum, $P$. verrucosum, $P$. cyclopium, $P$. canescens, $P$. madriti, $P$. palitans, $P$. thomii, $P$. baarnense, $P$. fenneliae, $P$. frequentans. These fungi have been reported to produce a number of toxins as citrinin (CTN), cyclopiazonic acid (CPA), ochratoxin A (OTA), patulin (PAT), penicillic acid (PA), penitrem A (PNT), roquefortine (RQF), frequentin (FRE), palitantin (PAL), mycophenolic acid (MPA), viomellein (VIM), gliotoxin (GT), citreoviridin (CIV), rubratoxin B (RB) [11-17]. These fungal species and their mycotoxins contaminate harvested seeds causing losses of agricultural commodities in many zones of the world. Such contaminants are fearsome, since they affect the seeds 
before harvest time and may find optimal developing conditions when the seeds are stored, leading to alteration of the germination quality of these seeds $[18,19]$.

Alternaria, Helminthosporium, Pyrenophora (sexual state: Drechslera), Phoma, and Zygosporium are genera of saprobic and plant pathogenic dematiaceous fungi with a world wide distribution, commonly associated with leaves, wood, cereals and other grasses. The species of these fungal genera are known to produce some dangerous mycotoxins such as cytochalasins and tenuazonic acid (TA).

Members of the genus Fusarium produce a range of chemically different phytotoxic compounds, such as fusaric acid (FA), fumonisins (fumonisin B1, FB1), beauvericin (BEA), enniatin (ENN), moniliformin (MON) and trichothecenes. These possess a variety of biological activities and cause morphological, physiological and metabolic effects including necrosis, chlorosis, growth inhibition, wilting, inhibition of seed germination and effects on calli [20-23]. Table 1 summarizes the general classes of mycotoxins with their producing fungal genera/species and chemical groups. Some of these mycotoxins are phytotoxic and others are non-phytotoxic. Mycotoxins with phytotoxic properties will be addressed below on the basis of their producing species. This review provides insight into characterization and evaluation of mycotoxins as phytotoxins. For each of the diverse groups of mycotoxins, we will give examples indicating history and fungi production with a focus on their modes of action and phytotoxic effects on several morphological and biochemical processes.

Table 1. Summary of the mycotoxins mentioned in the text. For references please refer to the text. The genus of the first isolation/description/main relevance is given.

\begin{tabular}{|c|c|c|c|}
\hline Name & Abbreviation & Species/Genus/Group & Chemical Group \\
\hline citreoviridin & CIV & Penicillium citreo-viride & pyranone derivative \\
\hline citrinin & CTN & $\begin{array}{c}\text { Penicillium, Monascus, } \\
\text { Aspergillus terreus }\end{array}$ & benzopyran compound \\
\hline cyclopiazonic acid & $\mathrm{CPA}$ & Penicillium, Aspergillus & indole tetramic acid \\
\hline frequentin & FRE & P. frequentans & carbocyclic compound \\
\hline gliotoxin & GT & A. fumigatus & epipolythiodioxopiperazine \\
\hline mycophenolic acid & MPA & Penicillium & meroterpenoid compound \\
\hline ochratoxin A & OTA & Aspergillus, Penicillium & benzopyran compound \\
\hline palitantin & PAL & Penicillium & cyclohexane derivative \\
\hline patulin & PAT & Penicillium, Aspergillus & benzopyran compound \\
\hline penicillic acid & PA & Penicillium, Aspergillus & isopropylidene tetronic acid \\
\hline penitrem A & PNT & Penicillium & indole diterpene alkaloid \\
\hline roquefortine & RQF & Penicillium & diketopiperazine compound \\
\hline rubratoxin $\mathrm{B}$ & $\mathrm{RB}$ & Penicillium rubrum & alpha, beta unsaturated lactone \\
\hline viomellein & VIM & Penicillium & benzopyran compound \\
\hline 3-acetyldeoxynivalenol & 3-ADON & Fusarium & trichothecenes, sesquiterpenoid \\
\hline 4-deoxynivalenol & DON & Fusarium & trichothecenes, sesquiterpenoid \\
\hline beauvericin & BEA & Fusarium & hexadepsipeptide compound \\
\hline diacetoxyscirpeno & DAS & Fusarium & trichothecenes, sesquiterpenoid \\
\hline enniatin & ENN & Fusarium & cyclic depsipeptide \\
\hline fumonisins & e.g., FB1 & Fusarium & monoterpenes \\
\hline
\end{tabular}


Table 1. Cont.

\begin{tabular}{lccc}
\hline Name & Abbreviation & Species/Genus/Group & Chemical Group \\
\hline fusaric acid & FA & Fusarium & $\begin{array}{c}\text { picolinic acid derivative, } \\
\text { carboxylic acid }\end{array}$ \\
HT-2 toxin & - & Fusarium & trichothecenes, sesquiterpenoid \\
moniliformin & MON & Fusarium & cyclobutane compound, dione \\
nivalenol & NIV & Fusarium & trichothecenes, sesquiterpenoid \\
T-2 toxin & - & Fusarium & trichothecenes, sesquiterpenoid \\
zearalenone/F-2 toxin & ZEA & Fusarium & estrogenic compound \\
aflatoxin & e.g., AFB1 & Aspergillus & difuranocoumarin derivative \\
tenuazonic acid & TA & Alternaria tenuis & 3-acetyltetramic acid \\
cytochalasin & e.g., CB & Phoma & polyketide-amino acid hybrid \\
\hline
\end{tabular}

2. Mycotoxins Produced by Aspergillus and Penicillium spp.

\subsection{Aflatoxins}

\subsubsection{Historical Perspective}

The discovery of aflatoxin has revolutionized research on molds and mold metabolites because of its potency as a toxin and carcinogen. The term "mycotoxin" has nearly become a household word, and aflatoxin has served as the model for research on and control of other mycotoxins that might otherwise have been unrecognized or neglected. In 1910, Kühl [24], a German pharmacologist, stated that Brazil nuts often were molded by Aspergillus flavus; the fungus was known to be toxic and probably made the nuts toxic. The discovery of aflatoxins began immediately after an outbreak, termed the Turkey-X-disease, appeared in England in the early months of 1960. In the course of a few months, deaths were reported of more than 100.000 young turkeys on poultry farms in England but deaths were also reported of thousands of ducklings and young pheasants on nearby farms [25]. Larger animals such as calves and pigs were also affected as well. Veterinarians and scientists of all kinds, pathologists, microbiologists, nutritionists, and chemists, were called on to seek a solution. All results of an intensive investigation were negative. None of about 50 different known chemical poisons they tested for could be found; no virus or bacterial infection and no new microorganism could be found. Eventually, the toxicity was traced to the feed, and more specifically to one ingredient in the feed, a peanut meal imported from Brazil [25]. Fortunately, a considerable quantity of this meal remained unused. During this time, the problem with turkeys in England was related to a similar problem with ducklings in Kenya. As a result, a test for the toxin was developed using ducklings which were particularly suitable for evaluation of toxicity based on death or the appearance of characteristic liver lesions [26,27].

The test was used to effectively monitor the extraction and concentration of the toxin by classical chemical procedures. The toxic extracts emitted a characteristic bright blue fluorescence when illuminated with ultraviolet light. Furthermore, the intensity of fluorescence, as estimated visually, generally afforded a convenient guide to the toxicity of the sample. This observation provided for the first time the basis for a routine chemical assay for the toxin [28]. About this time, in relation to the outbreak in Kenya, it was determined that the toxin is produced by the common mold Aspergillus flavus. So, the name aflatoxin was coined from Aspergillus flavus toxin [29]. By 1963, the structures of 
some of aflatoxins were being elucidated, culminating with the publication by Asao et al. of the currently accepted configurations [30].

\subsubsection{Producing Fungal Species}

Aflatoxins are difuranocoumarin derivatives produced in a polyketide pathway by many strains of Aspergillus flavus and A. parasiticus, in particular, A. flavus which is a common contaminant in agriculture. Among 18 different types of aflatoxins produced by A. flavus strains, aflatoxin B1 (AFB1, Figure 1) is the most extremely toxic, mutagenic and carcinogenic type [31,32]. Thus, numerous studies have been conducted to determine the effects of various food additives, preservatives, chemicals and environmental conditions to inhibit growth and aflatoxin production effectively [33-38].

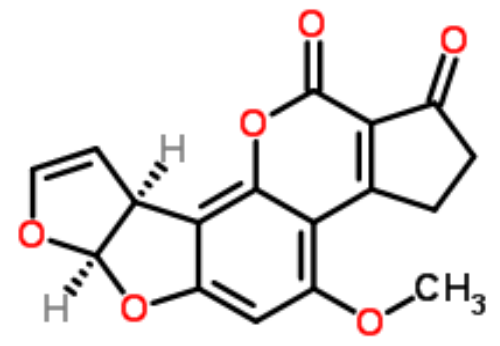

Figure 1. Chemical structure of Aflatoxin $\mathrm{B} 1$ (AFB1) $\left(\mathrm{C}_{17} \mathrm{H}_{12} \mathrm{O}_{6}\right)$, taken from ChemSpider [39], 162470.

\subsubsection{Phytotoxicity}

The phytotoxic effect of aflatoxin was observed on the basis of the remarkable inhibitory effect on chlorophyll and carotenoid synthesis and reduction of seed germination and seedling growth of lettuce [40], mung [41], mustard, gram [42], cowpea [43] and sesame [44]. Aflatoxin has been proposed to inhibit chlorophyll synthesis which results in the virescence or albinism in the affected plants [45]. The phytotoxic effects of AFB1 on in vitro cultures of regenerating plantlets of Nicotiana tabacum showed that root and leaf development, and root and leaf mass were significantly inhibited in a dose-dependent fashion with increasing AFB1 concentration above $0.5 \mu \mathrm{g} \cdot \mathrm{mL}^{-1}$, and root development was more seriously affected than leaf development [46]. The inhibition dose for $50 \%$ reduction $\left(\mathrm{LD}_{50}\right)$ in seedling viability was recorded by aflatoxins at $0.83 \mathrm{mg} \cdot \mathrm{L}^{-1}$ for barley, $1.74 \mathrm{mg} \cdot \mathrm{L}^{-1}$ for wheat and $2.75 \mathrm{mg} \cdot \mathrm{L}^{-1}$ for sorghum [47]. Aflatoxin at concentrations higher than $10 \mu \mathrm{g} \cdot \mathrm{mL}^{-1}$, induced the maximal reduction in the growth rate of hypocotyls after germination. This was discussed in relation to the effects of aflatoxin on DNA-dependent RNA biosynthesis [40]. Reduction in the number of tillers in plants treated with high concentrations of aflatoxin was also due to the accumulation of DNA damage in cells, which leads to apoptosis [48].

Electron microscopic studies also revealed the inhibition of grana formation in chloroplasts of maize leaves treated with aflatoxins [49]. At higher toxin concentrations, inhibition of root and shoot elongation was accompanied ultrastructurally by derangement of cytoplasmic constituents, dissolution of membranes, particularly the tonoplast, loss of ribosomes, organellar disruption and disappearance of 
the endoplasmic reticulum. The increased inhibition of root and shoot extension as AFB1 concentration increased was suggested to be correlated with the increasing disruption of the organelles [8].

\subsubsection{Mechanism of Action}

Aflatoxin inhibition of chlorophyll $a$, chlorophyll $b$ and protochlorophyllide biosynthesis in mung bean seeds (Vigna radiata) has been studied [41]. Suppression of protein and nucleic acid levels by aflatoxin has been also observed in germinating maize [50] and mung seeds [41]. Aflatoxin inhibits chromatin bound DNA-dependent polymerase activity. Inhibition of protein synthesis was attributed to the non-availability of m-RNA, whereas inhibition of DNA synthesis was due to the binding of aflatoxin to DNA during replication or due to the inhibition of DNA polymerase [50]. In tobacco plantlets (and also in Zea mays root tips), AFB1 has been immunolocated in the nucleus of stem cells [51]. Reduction in number of tillers in plants treated with aflatoxin may be due to the accumulation of DNA damage in cells, which leads to apoptosis [48]. Aflatoxin was reported to arrest cell cycle and induce apoptosis in cultured cells [48]. The apoptotic pathway is the only option for a cell when DNA repair systems are overburdened due to too many damages. Vogelstein and Kinzler [52] have shown that among its diverse functions, the p53 gene normally prevents DNA replication in cells that have DNA damage by maintaining the cell in G2/M phase allowing more opportunity for DNA repair. Cells with inactivated p53 might therefore survive abnormally and allow further DNA damage to accumulate [53], a situation, which favors carcinogenesis [54]. AFB1 exhibited genotoxic effect in wheat plants and several types of chromosomal aberrations have been detected during meiosis after application; these aberrations included chromosome stickiness, outside bivalents, bridges, laggards, unequal division and micronuclei [48].

\subsection{Citrinin}

\subsubsection{Historical Perspective and Producing Fungal Species}

Citrinin (CTN, Figure 2) is a benzopyran compound first isolated by Hetherington and Raistrick from a culture of Penicillium citrinum Thom [55]. Meanwhile, several other fungal species within the three genera, Penicillium ( $P$. expansum, P. verrucosum), Aspergillus (A. terreus), and Monascus (M. ruber) were also found to produce this mycotoxin [56,57]. CTN contaminates maize [58], wheat, rye, barley, oats [59], and rice [60]. CTN has antibiotic properties against gram-positive bacteria, but it has never been used as a drug due to its high nephrotoxicity. The kidney is the major target organ of CTN toxicity, but other target organs such as liver and bone marrow have also been reported [61].

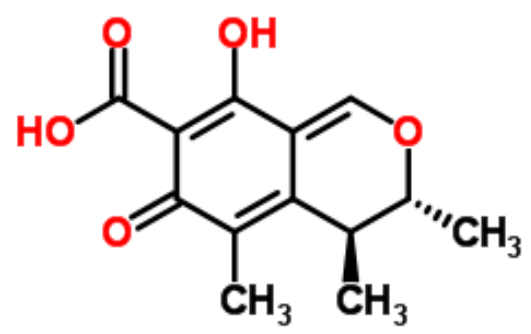

Figure 2. Chemical structure of citrinin $(\mathrm{CTN})\left(\mathrm{C}_{13} \mathrm{H}_{14} \mathrm{O}_{5}\right)$, taken from ChemSpider [39], 10222475. 


\subsubsection{Phytotoxicity}

It was shown to be phytotoxic in several trials [62-65]. It was proved to have remarkable phytotoxic effects. Damodaran et al. [63] found that CTN exhibits a wilting effect on bean plants (Dolichos lablab, Phaseolus vulgaris and Phaseolus mungo Co-1), two types of cotton (Gossypium arboreum K6 and 0320-1) and sorghum (Sorghum vulgare Co-20). Mać1as et al. [65] evaluated CTN ability to inhibit seed germination and seedling growth of Amaranthus hypochondriacus and Echinochloa crusgalli. These authors found that CTN reduced the radicle growth of both target species in a concentration-dependent manner recording $\mathrm{IC}_{50}$ of $5.5 \times 10^{-5} \mathrm{M}$ and $6.3 \times 10^{-5} \mathrm{M}$, respectively.

\subsubsection{Mechanism of Action}

The data on the mechanism of its phytotoxicity are still controversial and most have been obtained in vitro. Damodaran et al. [63] interpreted CTN phytotoxicity on the basis of its ability to bind with the cellular components present along the vascular system, and possibly also in the leaves also, and thereby affecting the osmotic balance and translocation. Another interpretation suggests that CTN may affect respiration of germinating seeds and seedlings. The same explanation has been interpreted for alteration of mitochondrial function of the baby hamster kidney cells by CTN [66]. This was confirmed by electron microscopy studies that showed that CTN significantly affected normal mitochondria with swelling and cell death. Chagas et al. [67] have suggested that CTN decreases $\mathrm{Ca}^{2+}$ accumulation in the matrix by inhibiting its influx and increasing its efflux. In Japan, CTN is associated with yellow rice disease [3].

\subsection{Patulin}

\subsubsection{Historical Perspective}

Patulin (4-hydroxy-4H-furo[3,2-c] pyran-2(6H)-one) (PAT, Figure 3), was originally isolated by Chain et al. [68] and named as claviformin due to its isolation from Penicillium claviforme, later it was renamed PAT according to the PAT-producing mold, Penicillium patulum (later called P. urticae, now P. griseofulvum) that was isolated by Birkinshaw et al. [69]. Later, PAT was isolated under various names; clavicin, clavitin, expansin, gigantic acid, leucopin, mycoin, penicidin and tercinin [70-73]. The early findings that PAT had antibiotic activity led to its testing against the common cold in humans $[74,75]$. PAT was soon found almost useless in curing the common cold [76] and was too toxic for use as an antimicrobial agent. It causes several human health effects including convulsions, nausea, ulceration, lung congestion, epithelial cell degeneration, carcinogenic, genotoxic, immunotoxic, immunosuppressive, and teratogenic [75,77].

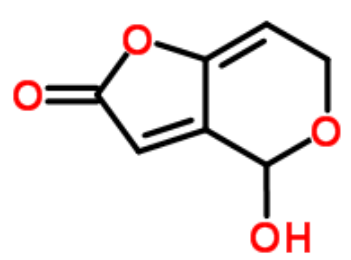

Figure 3. Chemical structure of patulin $(\mathrm{PAT})\left(\mathrm{C}_{7} \mathrm{H}_{6} \mathrm{O}_{4}\right)$, taken from ChemSpider [39], 4534. 


\subsubsection{Producing Fungal Species}

Steiman et al. [78] found that PAT production is not a generic character, although Aspergillus and Penicillium are by far the most extensively represented. It has been isolated from P. expansum [79] (P. leucopus [80], P. vulpinum [17] (P. claviforme [68]), P. griseofulvum [79] (P. patulum [69]), P. carneum, P. clavigerum, P. concentricum, P. coprobium, P. dipodomyicola, P. glandicola, P. gladioli, P. marinum, P. paneum, P. sclerotigenum [81], P. cyclopium [82], P. granulatum (P. divergens [83]), P. melinii, P. lapidosum [82], P. aurantiogriseum, P. canescens, P. chrysogenum, P. roqueforti, P. variabile [78], P. purpurogenum [84], Aspergillus clavatus, A. giganteus, A. longivesica [85], A. terreus [86], Byssochlamys fulva, B. nivea and Paecilomyces saturatus [87,88]. PAT has been detected in apples and apple products, and occasionally in other fruits such as pears, apricots, peaches and grapes [77]. It has also become a quality indicator of fruit used for the production of apple juice concentrates [89]. It is mainly produced in rotten parts of the fruits after infestation with PAT-producing fungus that can occur at $0{ }^{\circ} \mathrm{C}$ during storage or develops rapidly when fruits are returned to room temperature [90]. PAT also appears to increase after storage when fruits remain at room temperature $\left(20{ }^{\circ} \mathrm{C}\right)$ for short periods of time, a common procedure in fruit processing industries [91]. Apples are considered as an important source of PAT since they are easily infected by Penicillium expansum and also display optimum factors for PAT production [92]. The European Union has recommended levels of PAT for fruit juices and their products $50 \mu \mathrm{g} \cdot \mathrm{kg}^{-1}$; for solid apple products including apple compote, apple puree $25 \mu \mathrm{g} \cdot \mathrm{kg}^{-1}$, and $10 \mu \mathrm{g} \cdot \mathrm{kg}^{-1}$ for products intended for infants [93].

\subsubsection{Phytotoxicity}

The phytotoxicity of PAT has been studied by several investigators. PAT has been isolated from soils where phytotoxicity was observed $[94,95]$. The toxic effect has been observed on germinating seeds, young seedlings, isolated plant tissue of wheat and maize and plants which had continuous applications of PAT until maturity. Inhibition of plant elongation phases due to PAT effect accompanied with reduction in seed number, seed weight, number of flowers and gain in biomass was observed when PAT in aqueous solution was applied to these cultivated plants $[17,96]$.

\subsubsection{Mechanism of Action}

The phytotoxic action of PAT may take place in several ways. The inhibition of protein, RNA and DNA synthesis occurs after intoxication of cell cultures, indicating a primary effect. The genotoxic effects might be related to its ability to react with sulfhydryl groups and induce oxidative damage [97]. Respiration seems to be inhibited by PAT at concentrations below toxic levels. Immediate respiratory inhibition in both germinating apple pollen and soybean suspension cultures by PAT was observed [98], but the effects on respiration are probably secondary. In a recent study [17], the mechanism of PAT phytotoxic action through its effect on the endogenous glutathione (GSH) concentration of maize seedlings was reported. Due to its electrophilic character, PAT has been reported to react in vitro with cellular nucleophiles such as proteins and GSH [17,99]. Various enzymes were inhibited by PAT, among them enzymes containing thiol groups, and alcohol and lactic dehydrogenases and muscle aldolase [100,101]. 


\subsection{Penicillic Acid}

\subsubsection{Historical Perspective and Tautomeric Formulae}

The mycotoxin penicillic acid (3-methoxy-5-methyl-4-oxo-2,5-hexadienoic acid) (PA) a secondary metabolite of Penicillium puberulum Bainier, was first isolated and named during the investigation of the possible connection between the incidence of pellagra and mold deterioration of maize [102]. These investigators showed that when P. puberulum was grown on corn-meal mush or on Raulin's medium, appreciable quantities of PA were formed. They described the general properties of PA, but did not determine its molecular constitution. In 1935, Oxford and Raistrick [103] found that cultures of Penicillium cyclopium Westling produced relatively large amounts of PA and this finding enabled Birkinshaw et al. [104] to prepare sufficient PA for a successful determination of its molecular constitution by analytical methods. In order to avoid confusion, it should be remembered that so far as is known at present, there is no relationship between PA and Fleming's penicillin, except the purely fortuitous choice of names for these two substances by their respective discoverers [105]. The properties and behavior of PA are adequately expressed (Figure 4) by the tautomeric formulae (I and II). The structural formula II may be rewritten as structure III, from which it appears that PA may be regarded as the $\beta$-methyl ether of $\gamma$-hydroxy- $\gamma$-isopropylidene tetronic acid. The biochemical importance of the tetronic acid structure has been discussed by Bentley and Keil [106]. They reported experiments designed to study the biosynthesis of PA (I). Their study was particularly interesting in view of the presence of an isopropylidene side chain in PA, a group occurring only infrequently in natural products. In aqueous solution, it exists completely in the pseudo acid form (cyclic form, II), whereas in alkali, the ionic form must be largely derived from the open structure (linear form, I) [18,107]. Its hazardous effects, carcinogenic nature and antibiotic activity made it a cause of concern [108-111].
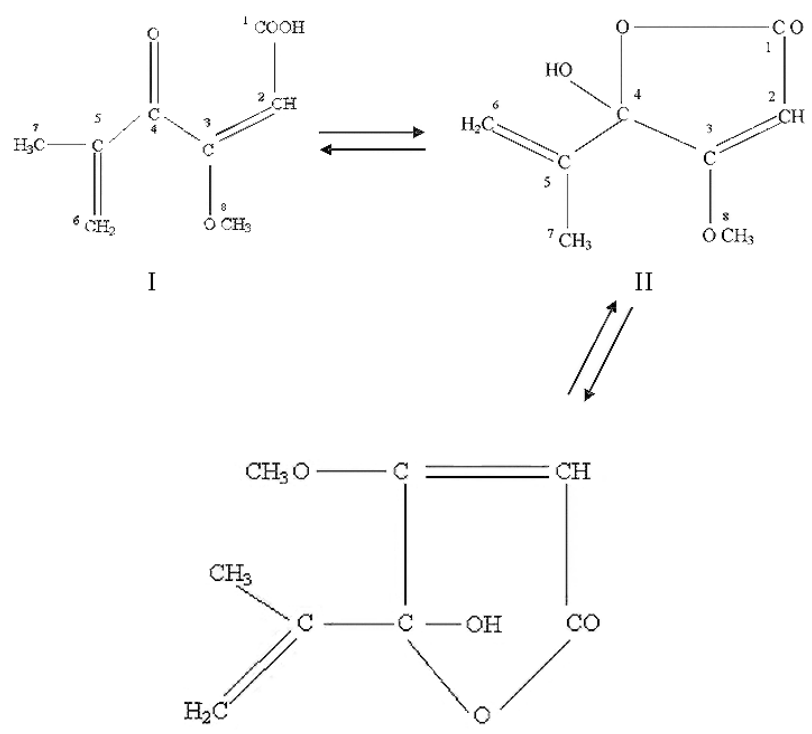

III

Figure 4. Structure of penicillic acid (PA) $\left(\mathrm{C}_{8} \mathrm{H}_{10} \mathrm{O}_{4}\right)$ showing tautomeric equilibrium with its lactone in aqueous solution, taken from [112]. 


\subsubsection{Producing Fungal Species}

Many fungi have been reported to be producers of PA, including the genus Penicillium and Aspergillus [113,114]. PA had been isolated from the following Penicillium species: P. viridicatum [115]. $P$. verrucosum [116], $P$. aurantiovirens [117], $P$. aurantiogriseum [14], P. tricolor [117], P. hirsutum [11,110], P. thomii [118], P. cyclopium [86], P. roqueforti [13], P. martensii, P. fenelliae, P. madriti, P. stoloniferum [119]. P. canescens [18], P. melanocladium, P. freii, P. polonicum, P. radicicola, P. tupliae, P. corneum [14] and P. frequentans [16]. Different Eupenicillium species such as E. bovifimosum, E. baarnese were also found to produce PA [120,121]. PA had been also produced by Aspergillus species such as: A. ochraceus [122], A. auricomus, A. melleus [119], A. alliaceus [123], A. ostianus [124], A. cervinus, A. wentii [109] and A. sclerotiorum [114]. The large number of strains capable of elaborating the mycotoxin PA indicates the ubiquity of penicillic acid-producing organisms in nature and the possibility for presence of this mycotoxin in stored high-moisture grains [119].

\subsubsection{Phytotoxicity}

The phytotoxicity of PA was discussed by its ability to lessen the seedlings respiration [125]. It was also reported to inhibit urease [126] and RNase [127] activity. Moreover, the toxic effects of PA have been considered to be caused by its reaction with enzymes and it has been shown to react with several amino acids to form less toxic products [128]. PA was reported to inhibit the growth of young plant roots of rice [129], Amaranthus hypochondriacus [130], corn [18], broad bean and pea [112]. PA was found to affect the overall turnover of the metabolites in Zea mays [131]. The phytotoxicity of PA was about 5\% that of AFB1 [18]. Browning of Picea glehnii roots and collapse in the root structure of lettuce were the main anatomical changes induced by PA on seedlings [16].

\subsubsection{Mechanism of Action}

The fact that PA is readily inactivated by thiols [128] has led to the hypothesis that the mode of action of this mycotoxin is due to its interaction with the SH-residues in enzymes. It has been found that the PA inhibits alcohol dehydrogenase and lactic dehydrogenase which are thiol enzymes $[100,132]$. PA was found to occur in high quantities (up to $2 \%$ dry weight) in infected corn [133] that it must be considered seriously. The seriousness of PA as phytotoxin was reported to increase due to its accumulation at the low temperatures $[18,134]$ of typical storage conditions.

\subsection{Ochratoxin}

\subsubsection{Historical Perspective and Producing Fungal Species}

Ochratoxin A (L-phenylalanine- $N$-[(5-chloro-3,4-dihydro-8-hydroxy-3-methyl-1-oxo-1H-2-benzopy rane-7-yl)carbonyl]-(R)-isocoumarin) (Figure 5, OTA) is a mycotoxin that was discovered to be a metabolite of Aspergillus ochraceus in 1965 during a large screen of fungal metabolites designed specifically to identify new mycotoxins [135]. Subsequent studies revealed that a variety of mold fungus species, including Aspergillus carbonarius [136], A. niger [137] and Penicillium verrucosum [138] 
were able to produce ochratoxins. Recently, A. westerdijkiae and A. steynii, two new species from the Aspergillus section Circumdati have been split from A. ochraceus and reported to be stronger OTA producers than A. ochraceus [139]. Penicillium nordicum and P. verrucosum are known to produce OTA, and have been frequently isolated from cereal crops, meat products and cheese varities [140,141]. Because of its widespread occurrence on a large variety of agricultural commodities and the potential health risks, mainly toward humans, OTA has been classified as a possible human carcinogen (group 2B) by the International Agency for Research on Cancer [142]. Given the known human exposure and the abundance of toxicological data from animal studies, the European Union Scientific Committee has recommended the OTA levels below to $5 \mathrm{ng} \cdot \mathrm{kg}^{-1}$ of body weight per day [143]. In the European Union, some regulatory limits have already been introduced for the levels of OTA in food products such as raw cereal grains $\left(5 \mu \mathrm{g} \cdot \mathrm{kg}^{-1}\right)$, products derived from cereals $\left(3 \mu \mathrm{g} \cdot \mathrm{kg}^{-1}\right)$, dried fruits $\left(10 \mu \mathrm{g} \cdot \mathrm{kg}^{-1}\right)$, roasted coffee and coffee products $\left(5 \mu \mathrm{g} \cdot \mathrm{kg}^{-1}\right)$, grape juice $\left(2 \mu \mathrm{g} \cdot \mathrm{kg}^{-1}\right)($ EC No 123/2005) and also for all types of wine $\left(2 \mu \mathrm{g} \cdot \mathrm{kg}^{-1}\right)$ (amended Regulation EC No. 466/2001).

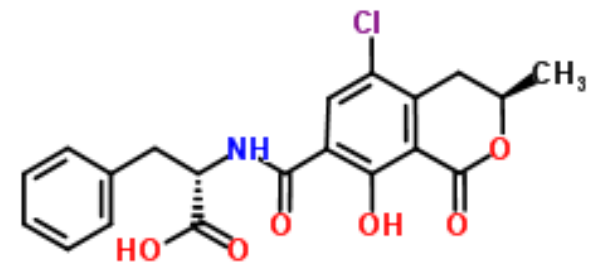

Figure 5. Chemical structure of ochratoxin $A$ (OTA) $\left(\mathrm{C}_{20} \mathrm{H}_{18} \mathrm{ClNO}_{6}\right)$, taken from ChemSpider [39], 390954.

\subsubsection{Phytotoxicity}

Recent studies have suggested that OTA induces cell death in plants [144]. OTA exposure can cause significant inhibition in the growth of plants on media and induce necrotic lesions in detached leaves of Arabidopsis thaliana. Moreover, preferential inhibition of root growth by OTA of seedlings was observed [145]. When OTA solutions (2 mM, $1 \mathrm{mM}$, or control) were infiltrated into leaves of 4-week-old $A$. thaliana plants grown in soil, macroscopic lesions formed on the infiltrated leaves within 1-2 days [144]. In the presence of OTA, the growth of $A$. thaliana on media was significantly inhibited; in addition, cell death was observed with features resembling the hypersensitive response-type lesions in excised leaves that were infiltrated with this toxin. There was also evidence that cell death was induced by OTA, such as the occurrence of an oxidative burst and the deposition of callose and phenolic compounds (autofluorescence) [145]. McLean [146] investigated the effect of OTA on germinating Zea mays embryos. He found that the measured effects on root and shoot growth at $10 \mu \mathrm{g} \cdot \mathrm{mL}^{-1}$ and $25 \mu \mathrm{g} \cdot \mathrm{mL}^{-1}$ were stimulatory, while at $5 \mu \mathrm{g} \cdot \mathrm{mL}^{-1}$ OTA, an inhibitory effect was observed.

\subsubsection{Mechanism of Action}

Several major mechanisms have been shown to be involved in the toxicity of OTA: inhibition of protein synthesis, interference with metabolic systems involving phenylalanine, promotion of membrane lipid peroxidation, disruption of calcium homeostasis, inhibition of mitochondrial 
respiration, and DNA damage [147]. Wang et al. [144] investigated the possible mechanisms of OTA phytotoxicity on A. thaliana and analyzed after application of OTA gene and protein expression. The authors summarized OTA phytotoxicity, as follows: First, exposure of excised A. thaliana leaves to OTA rapidly causes the hypersensitive response, significantly accelerates the increase of reactive oxygen species (ROS) and malondialdehyde, and enhances antioxidant enzyme defense responses and xenobiotic detoxification. Secondly, OTA stimulation causes dynamic changes in the expression of transcription factors and activates the membrane transport system dramatically. Thirdly, a concomitant persistence of compromised photosynthesis and photorespiration is indicative of a metabolic shift from a highly active to a weak state. Finally, the data revealed that ethylene, salicylic acid, jasmonic acid, and mitogen-activated protein kinase signalling molecules mediate the process of toxicity caused by OTA. Wang et al. [148] studied the changes in biosynthesis and metabolism of GSH upon OTA stress in A. thaliana and found accumulation of GSH in the detached leaves of $A$. thaliana under OTA treatment. The authors revealed that OTA stimulated a defense response through enhancing glutathione- $S$-transferase, glutathione peroxidase, glutathione reductase activities, and the transcript levels of these enzymes were increased to maintain the total glutathione content. Moreover, the level of oxidized glutathione (GSSG) was increased and the ascorbate-glutathione cycle fluctuated in response to OTA.

\section{Mycotoxins Produced by Dematiaceous Hyphomycetes}

\subsection{Tenuazonic Acid}

\subsubsection{Historical Perspective and Tautomeric Formulae}

The tetramic acid derivative L-tenuazonic acid [(5s,8s)-3-acetyl-5-sec-butyl-pyrrolidine-2,4-dione] (TA) was first isolated by Rosett et al. [149], from Alternaria tenuis, a dematiaceous plant pathogen invading a series of plants involved in the postharvest decay of fruits, grains and vegetables. Its structure was established by Stickings [150] and later investigated by Wessels and co-workers [151] applying NMR spectroscopy and X-ray crystallography, also describing different tautomers of this 3-acetyltetramic acid. Nevertheless it was not possible to distinguish between different tautomers equilibrating fast on NMR scale and therefore the structure of TA is still not clear, especially in aqueous solution. Varying structures of TA are still widely used in the literature, resulting in different CAS registry numbers. Figure 6 shows the TA structures and tautomerism of 3-acetyltetramic acids which may lead to wrong structural information for further research. For a better understanding of the structure of TA, the tautomerism as well as important equilibria (fast and slow), all reasonable tautomers and rotamers of TA have been subjected to quantum chemical calculations at an adequate level of theory. NMR spectra were calculated and compared to experimental data, finally leading to a synergetic computational and spectroscopic approach for structural investigations of TA and 3-acetyltetramic acids in general [152]. Its biological activity was first described by Shigeura and Gordon [153]. Later, it was isolated from Magnaporthe grisea (the blast fungus, former name is Pyricularia oryzae) as a phytotoxin [154] and from Alternaria longiceps, A. kikuchiana, A. mali, A. alternata, A. tenuissima and Phoma sorghina as a mycotoxin [155-159]. Additionally, TA has been 
made responsible for the outbreak of "onyalai" a human hematologic disorder disease occurring in Africa after consumption of sorghum [159].<smiles>CC[C@H](C)[C@H]1NC(=O)/C(=C(/C)O)C1=O</smiles>

CAS 75652-74-3

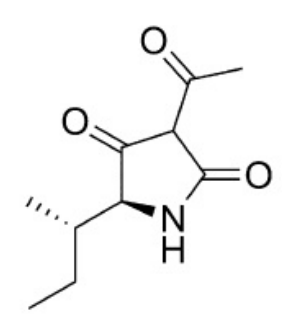

CAS 27778-66-1<smiles>CC[C@H](C)[C@H]1NC(=O)C(C(C)=O)=C1O</smiles>

CAS 610-88-8

B<smiles></smiles>

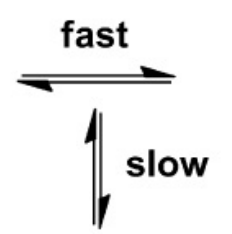<smiles>[R]C1NC2=COPC(C)=C2C1=O</smiles><smiles>[R]C1NC(=O)[C@H](C(C)=O)C1=O</smiles><smiles>[R]C1NC(=O)C2=C(C)O[CH]O[C@@H]21</smiles>

Figure 6. (A) Different structures of tenuazonic acid (TA) taken from [152] and (B) tautomerism of 3-acetyltetramic acids, taken from [152].

\subsubsection{Phytotoxicity}

TA exhibited significant phytotoxic effects on monocotyledonous and dicotyledonous plants and thus is a non-spccific phytotoxin [160]. The relationships between the structures and the phytotoxicity of TA were assessed by Lebrun et al. [161]. These authors further showed that TA also induces a leaf necrosis on all rice varieties as well as the browning of the edges of dead areas on reactive varieties. Janardhanan and Husain [160] found that TA produced localized chlorotic spots in Datura innoxia which enlarged, turned to necrotic after $24 \mathrm{~h}$ of $200 \mu \mathrm{g} \cdot \mathrm{mL}^{-1} \mathrm{TA}$ application. Similar phytotoxic effects on leaves of $D$. metel, D. stramonium, belladonna, cowpea, wheat, rye and maize were observed at the same concentration of TA. The authors further indicated that TA inhibited growth of germinating seeds of $D$. innoxia, wheat, rye, lettuce and green gram at $100 \mu \mathrm{g} \cdot \mathrm{mL}^{-1}$. TA was found to induce small brown necrotic spots on leaves and may also favor ROS production in planta [154].

\subsubsection{Mechanism of Action}

The inhibition of plant cells growth by TA is thought to be caused by the inhibition of protein synthesis $[153,157]$ at the ribosome level [162]. It has been shown that TA has a ribosome binding site as it inhibits the binding of radioactive protein synthesis inhibitors (anisomycine and trichodermin) on the ribosome [163,164]. It was also reported that TA forms complexes with ions, including iron or copper [161]. TA showed no appreciable change in the rate of respiration of leaves, and the toxin 
treatment had no significant effect on total sugar and phenol contents, however a reduction in chlorophyll and protein content of leaves was noticed [160]. Findings of Park [165] on the ultrastructure of parenchyma cells of Japanese pear leaves treated with TA supported the toxic effect of TA on the basis of degeneration of chloroplast and endoplasmic reticulum in leaf tissue near the treated area with toxin.

\subsection{Cytochalasins}

\subsubsection{Historical Perspective and Producing Fungal Species}

The metabolites isolated from a Phoma species have been called phomins. Those from Zygosporium masonii Huges were named zygosporins. The metabolites from Helminthosporium species were described as cytochalasins (cytos: cell; chalasis: relaxation). The three groups proposed a systemic nomenclature based on the generic name cytochalasan for the cytochalasins, phomins and zygosporins [166]. Phomin (phomine, cytochalasin B, CB), the first cytochalasin reported, was described in 1966 as a macrolide antibiotic with cytostatic activity produced by a Phoma species [167]. Later, in a more detailed investigation of the Phoma metabolites, a closely related compound with similar activity, dehydrophomin (cytochalasin A, CA), was isolated [168]. In 1967, Aldridge et al. [169] isolated CA and $\mathrm{CB}$ from Helminthosporium dematioideum (Drechslera dematioidea) and CD and CD from Metarhizium anisopliae (Metsch.) Sorok. Earlier, a French patent reported that CA and CB produced by $H$. dematioideum (D. dematioidea) contained nitrogen. These compounds are intraconvertible by oxidation-reduction reactions and had the empirical formulas of $\mathrm{C}_{29} \mathrm{H}_{35} \mathrm{NO}_{5}$ and $\mathrm{C}_{29} \mathrm{H}_{37} \mathrm{NO}_{5}$.

Cytochalasins are a group of polyketide-amino acid hybrid compounds belong to the cytochalasan family of fungal secondary metabolites, which have significant commercial and research values due to their diverse arrays of biological activities and complex molecular structures. Over 80 different cytochalasans have been isolated from a number of the fungal genera, including Aspergillus, Phomopsis, Penicillium, Zygosporium, Chaetomium, Rosellinia, Metarhizium, etc. [170]. Of these, CB (Figure 7) is the most widely studied and has been extensively used for cytological investigations [171-175]. It has been previously extracted from various phytopathogenic fungi such as D. dematioidea [169], Helminthosporium solani [176] and Phoma exigua strain 298, P. exigua var. exigua on potatoes [177], Aschochyta heteromorpha on chickpea [178] and from Drechslera wirreganensis and D. campanulata on cereal [179].

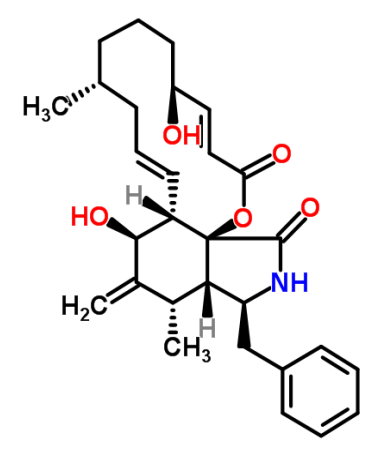

Figure 7. Chemical structure of cytochalasin B (CB) $\left(\mathrm{C}_{29} \mathrm{H}_{37} \mathrm{NO}_{5}\right)$, taken from ChemSpider [39], 4895549. 


\subsubsection{Phytoxicity and Mechanism of Action}

Carlier et al. [180] showed the mechanism of cell toxicity by cytochalasin, as follows: Cytoskeleton $\rightarrow$ disruption of endocytosis $\rightarrow$ cell deregulation $\rightarrow$ cell death. CB inhibited exudation in maize roots [181] and reduced fiber production of cotton ovules [182]. It significantly inhibited flax radical growth [183], stomatal movement in Vicia faba L. [184] and pollen tube growth in Luffa cylindrica (L. aegyptiaca) Mill. [185]. Kadota and Wada [186] found that the treatment of the tip growing protonemal cell of the fern Adiantum spp. with CB caused disruption of the microfilament strands, cessation of tip growth and stopping of nuclear movement. Treatment of the Fasciola hepatica spermatogenic cells with CB caused formation of bi- and multi-nucleated cells [187]. Tamagnini et al. [188] reported that treatment of Pisum sativum L. with CB decreased the respiration rate. They also observed that treated cotyledonary axis and cotyledons had higher contents of starch, soluble sugars and proteins but the phosphatase activity became lower than control. CB decreased the total respiratory rate in leaves of winter wheat cv. Mironovskaya 808 [189]. Cytochalasin was reported to have a morphogenetic effect on Allium cepa L. roots by producing a reversible inhibition of mitosis and axis elongation [176,190-192].

CA blocked the accumulation of phytoalexin and phenylalanine ammonia-lyase in pea tissues [193]. $\mathrm{CD}$ altered the actinomycin system of the onion epidermal cells, disintegrated the actin filaments and caused formation of large flat-sheet-like cytoplasmic reticulum sacs in the epidermal cells of onion [194]. Treatment of the microspores of Brassica napus L. cv. Topas with CD resulted in dislocated mitotic spindles, disrupted phragmoplasts, symmetric divisions and finally embryogenesis [195]. Traas et al. [196] found that $\mathrm{CB}$ and $\mathrm{CD}$ affected the organization of spindle microtubules, during meiosis in eggplant (Solanum melongena L.).

CE was found to be a phytotoxic metabolite to apple and lettuce plants [197,198]. It also inhibited seed germination of Striga hermonthica Lour. [199] and showed a direct effect on photosynthesis of young leaves of Malus domestica Borkh. (Malus pumila) as detected by chlorophyll fluorescence [200].

Pyrenophora semeniperda (a naturally occurring ascomycete seed pathogen) was reported to produce phytotoxins belonging to a different class of natural compounds when grown in solid culture on wheat seeds. This fungal species produced a large amount of the phytotoxic $\mathrm{CB}$, as well as $\mathrm{CA}, \mathrm{CF}$, deoxaphomin, and the three novel cytochalasins, Z1, Z2, and Z3 [201]. Masi et al. [202] found that $P$. semeniperda was also able to produce phytotoxic sesquiterpenoid penta-2,4-dienoic acid, named pyrenophoric acid which showed strong phytotoxicity on cheatgrass, reducing coleoptile length relative to the control by approximately half at $10^{-3} \mathrm{M}$ and by $23 \%$ at $10^{-4} \mathrm{M}$. CB at $10^{-4} \mathrm{M}$ reduced coleoptile elongation $15 \%$, and the combination of pyrenophoric acid and $\mathrm{CB}$ at $10^{-4} \mathrm{M}$ reduced coleoptile elongation $36 \%$ relative to the control. The authors indicated that these two compounds exhibited an additive rather than a synergistic toxicity effect, as the combined effect was essentially the sum of the effects of the two compounds applied singly. The phytotoxicity of pyrenophoric acid helped them to explain why organic extract phytotoxicity was not correlated with $\mathrm{CB}$ concentration in their earlier study [203]. Pyrichalasin H (is another type of cytoclasins family), isolated from a Digitaria isolate (IFO 7287) of the blast fungus, inhibited the growth of rice seed and induced characteristic curling of the shoot at $1 \mu \mathrm{g} \cdot \mathrm{mL}^{-1}$, but did not induce any visible symptoms on the rice leaf [204]. Zygosporin D and two new cytochalasins were isolated from Metarhizium anisopliae. Of these cytochalasins, only zygosporin D was an effective inhibitor of shoot elongation of rice seedlings [205]. 


\section{Mycotoxins Produced by Fusarium and Other Species}

\subsection{Trichothecenes}

\subsubsection{Historical Perspective and Producing Fungal Species}

Trichothecenes belong to a major class of mycotoxins produced by a range of fungi from the order Hypocreales, including those of the genera Fusarium, Myrothecium, Verticimonosporium, Stachybotrys, Trichoderma, Trichothecium, Cephalosporium, and Cylindrocarpon [170,206-209]. More than 120 trichothecenes are known. These compounds have been isolated in the past thirty years. The first trichothecene to be isolated was trichothecin from Trichotheceum roseum, in 1948 by Freeman and Morrison [210]. Diacetoxyscirpenol (DAS) from Fusarium equiseti was preliminarily characterized in 1961 by Brian et al. [211], and was later followed by nivalenol (NIV) [212] and T-2 toxin [213], both from $F$. sporotrichioides, although they were mis-identified as $F$. nivale and $F$. tricinctum, respectively, in the original articles [214]. However, it was the discovery of 4-deoxynivalenol (DON) from wheat in Eastern North America in 1980 [215], which truly sparked the research into the Fusarium species and led to the discovery of trichothecenes from other genera.

Trichothecenes are a large group of sesquiterpenoid fungal metabolites, which share a common core comprised of a rigid tetracyclic ring system (Figure 8) consisting of a cyclohexene, A-ring with a double C-C bond occurring between C-9 and C-10; a tetrahydropyranyl B-ring; a cyclopentyl C-ring, and an epoxide at $\mathrm{C}-12 / 13$. The rigidity of this system results in a distinct stereochemistry for the A- and B-rings. The A-ring adopts a half-chair conformation, and the B-ring is most often found in the chair conformation (Figure 9a) [216,217], although there have been a few odd cases where the B-ring has been shown to adopt a boat conformation (Figure 9b) [218]. Shank et al. [219] reviewed the types of trichothecenes and showed that they fall into two main classes, simple and macrocyclic [170,220,221]. The simple trichothecenes are further divided into three types; A, B and C. Type A trichothecenes are the simplest group, being non-substituted, hydroxylated or esterified (Figure 10). Type B trichothecenes are characterized by a ketone present at C-8 (Figure 10) Type A and B trichothecenes, such as T-2 toxin and DON, respectively, are often associated with Fusarium-infected grain. Type C trichothecenes, such as crotocin [222], are less common than the others, and are distinguished by the presence of a second epoxide ring at C-7/8 (Figure 10). A fourth class (Type D), are characterized by the presence of a cyclic diester or triester linkage of C-4 to C-15 (Figure 10) (30). These macrocyclic trichothecenes include the satratoxins, verrucarins, roridins, myrotoxins and baccharinoids. While many of the Type D trichothecenes have been isolated from fungi, the baccharinoids were first isolated from the plant Baccharis spp. [223]. Although early reports suggested that the metabolites were produced by the plant itself, later studies indicated that the toxins were likely the product of a Hypocrealean endophyte (the order to which trichothecene-producing fungi such as Fusarium, Myrothecium and Stachybotrys belong) within the plants [224]. 


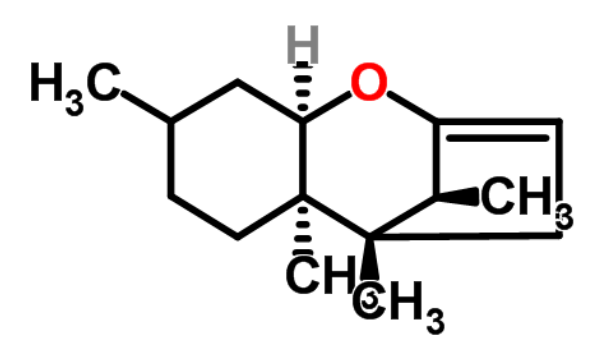

Figure 8. Chemical structure of the trichothecene core, taken from ChemSpider [39], 20004967.
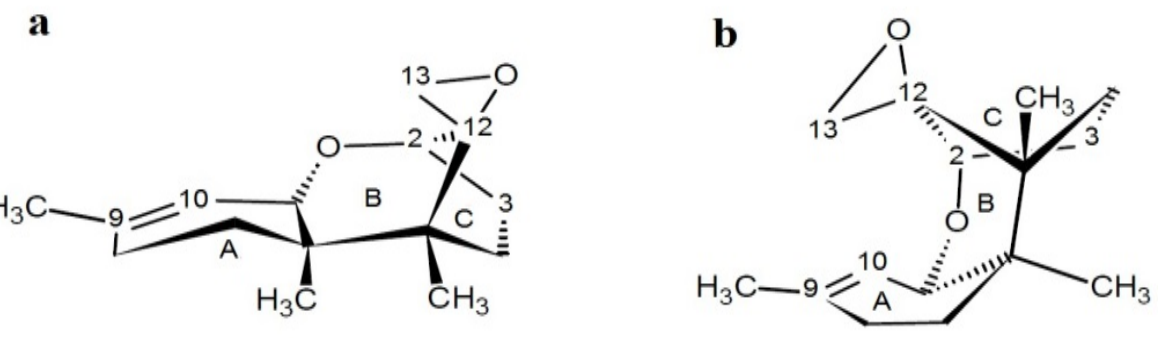

Figure 9. Three-dimensional stereochemistry of the trichothecene core when (a) the A-ring is in a half-chair, and the B-ring in a chair conformation; and (b) the A-ring is a half-chair, and the B-ring in a boat conformation, taken from Shank et al. [219].
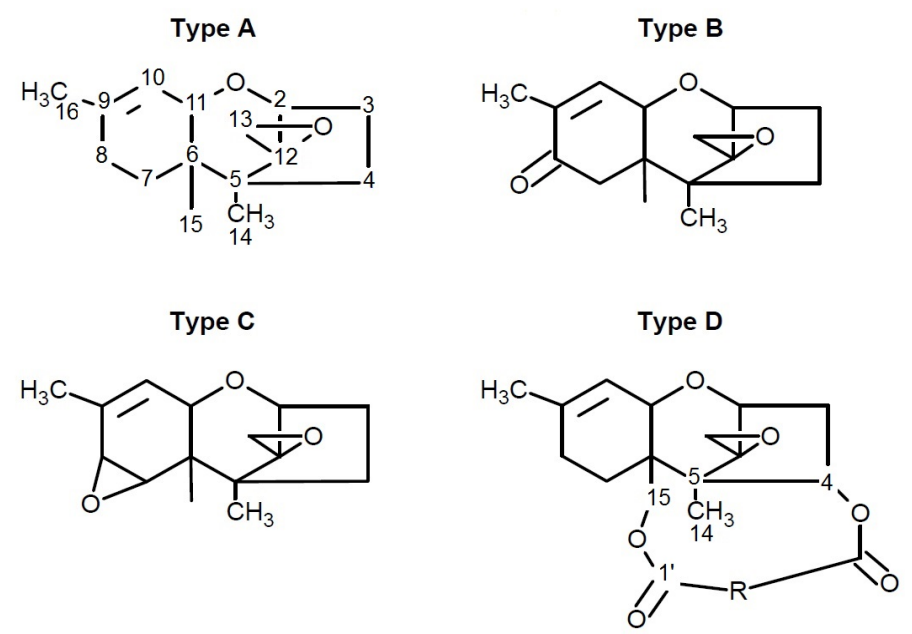

Figure 10. The general core structures for Type A, B, C, and D trichothecenes, taken from [219].

\subsubsection{Phytotoxicity and Mechanism of Action}

In plants, tricothecenes produced by Fusarium spp. cause necrosis, chlorosis, and mortality enabling them to mediate a wide variety of plant diseases, including wilts, stalk rot, root rot and leaf rot in many important crop and ornamental plants [225-230]. Examples include kudzu [231], Orobanche [232], duckweed [233], and many grain crops [234,235]. The phytotoxicity of some examples of tricothecenes can be characterized, as follows: 


\subsubsection{Deoxynivalenol (Vomitoxin) (DON) and Nivalenol (NIV)}

DON (3,7,15-trihydroxy-12-13-epoxytrichothec-9-en-8-one; F. graminearum; F. culmorum) and NIV $(3 \alpha, 4 \beta, 7 \alpha, 15$-tetrahydroxy-12,13-epoxytrichothec-9-en-8-one; F. graminearum; $F$. sporotrichioides; F. crookwellense) [22,217,236] play a role as virulence factors in disease development [237,238]. Wakulinski [239], using seedlings of three wheat varieties to assess the phytotoxic effects of six Fusarium metabolites, found DON and 3-acetyldeoxynivalenol (3-ADON) to be the inhibitoriest of germination and root development generally appeared to be the most sensitive to the metabolites. The phytotoxic effects of DON and 3-ADON were observed at 10 to 100 -fold lower concentrations than those observed for ZEA, T-2 toxin and diacetyoxyscirpenol (DAS). Rocha et al. [240] summarized the phytotoxic effects of DON as growth retardation, inhibition of seedling and green plant regeneration. Shimada and Otani [241] measured similar inhibitory effects of DON on root development in seven varieties of wheat seedlings. A concentration of approximately $10 \mu \mathrm{g} \cdot \mathrm{mL}^{-1} \mathrm{DON}$ resulted in a $50 \%$ inhibition of shoot growth, while for roots, this value was five-fold lower (approximately $2 \mu \mathrm{g} \cdot \mathrm{mL}^{-1}$ ) [241]. NIV was less phytotoxic: $100 \mu \mathrm{g} \cdot \mathrm{mL}^{-1}$ and $48 \mu \mathrm{g} \cdot \mathrm{mL}^{-1}$ caused a $50 \%$ inhibition of shoot and root growth, respectively [241]. DON was shown to be more phytotoxic to corn genotypes susceptible to gibberella ear rot than resistant genotypes [242]. Bottalico et al. [243] have reported DON to be inhibitorier of root growth than of shoot/leaf growth in tomato seedlings. In wheat seeds, $50 \mu \mathrm{g} \cdot \mathrm{mL}^{-1}$ DON completely inhibited germination, while $10-25 \mu \mathrm{g} \cdot \mathrm{mL}^{-1}$ significantly reduced plantlet growth [244].

The DON toxin caused greater damage to the membranes of the susceptible genotypes, as evidenced by the release of $\mathrm{Na}$ and $\mathrm{K}$ ions into solution [242]. DON concentrations above and including $50 \mathrm{ppm}$ resulted in virtual suppression of calli regeneration (calli forming shoots) of three wheat genotypes, while 100 ppm DON was lethal to most calli [245]. Packa [246] found a decrease in the mitotic index of roots from germinated caryopses of rye, wheat, triticale and field bean treated with $10 \mu \mathrm{g} \cdot \mathrm{mL}^{-1} \mathrm{a}$ DON for $24 \mathrm{~h}$. Inhibitory effects on mitosis were observed primarily in wheat and field bean. Chromosome and nuclear abnormalities included spiralisation of metaphase chromosomes and numerous ana- and telophase bridges [246]. In dividing root tip cells of onion, DON resulted in a decline in the mitotic index and relative division rate [247]. A toxin dose of $2.5 \mathrm{ppm}$ reduced the relative division rate to $78 \%$ that of controls. DON $\left(10 \mu \mathrm{g} \cdot \mathrm{mL}^{-1}\right.$ and $\left.25 \mu \mathrm{g} \cdot \mathrm{mL}^{-1}\right)$ significantly inhibited both primary root and shoot elongation of excised, germinating Zea mays embryos following 9 days of toxin exposure. Seedling root mass was $43.5 \%$ and $45.6 \%$ of the control value for $10 \mu \mathrm{g} \cdot \mathrm{mL}^{-1}$ and $25 \mu \mathrm{g} \cdot \mathrm{mL}^{-1} \mathrm{DON}$, respectively. For shoot fresh mass, these values were slightly lower: $19.2 \%$ and $25.5 \%$, respectively [246]. DON was demonstrated to interfere with the synthesis of kernel storage proteins (and presumably other processes, e.g., lignification) [248]. In wheat seedlings sensitive to both F. culmorum and DON, free proline level increases have been reported, but were influenced by cultivar and DON concentration [244]. The increased proline levels have been interpreted as a plant response to pathogen attack [244]. It is possible that elevated proline levels may reflect an inhibitory effect on protein synthesis (i.e., failure to incorporate proline into proteins) [146]. Snijders and Kretching (1992) showed that DON is essential for F. graminearum colonization of plants. DON, as an inhibitor of protein synthesis, would inhibit the production of host enzymes (normally elaborated in response to fungal presence), thereby allowing fungal spread [249]. 
Additionally, DON being water-soluble, may be distributed to the spike and kernel by phloem vessels, thus promoting fungal proliferation by inhibiting the plant response [238].

\subsubsection{Diacetyoxyscirpenol (DAS)}

DAS (3,4-diactyoxyhydroxy-15-hydroxy-12,13-epoxytrichothec-9-ene; $F . \quad$ graminearum; F. sambicinum; F. poae; F. equiseti) [22,217,236]. It is known clinically as anguine [22]. DAS was reported to reduce seedling viability and the inhibition dose for $50 \%$ reduction (LD50) was at $1.26 \mathrm{mg} \cdot \mathrm{L}^{-1}$ for barley, $3.98 \mathrm{mg} \cdot \mathrm{L}^{-1}$ for wheat and $10 \mathrm{mg} \cdot \mathrm{L}^{-1}$ for sorghum [47]. Germinating caryopses of rye and field beans, and to a lesser extent, triticale and wheat, were sensitive to $10 \mu \mathrm{g} \cdot \mathrm{mL}^{-1} \mathrm{DAS}$, resulting in a decrease in the mitotic index [246]. For rye and beans, the number of cells found in metaphase increased with respect to other stages, as did metaphase chromosome abnormalities (spiralisation, C-metaphases, increased chromosome number and stellate chromosomes) [246]. Such chromosomal abnormalities result from an interference with the mitotic spindle, which may in turn have arisen from a disruption of protein synthesis, particularly of spindle microtubular proteins [246]. Inhibitory effects of DAS on root growth were more marked than for leaf mass of wheat seedlings [239]. DAS was less toxic than DON, 3-ADON, MON and T-2 toxin on germination and root and leaf mass, however more toxic than F-2 toxin [239].

\subsubsection{T-2 Toxin}

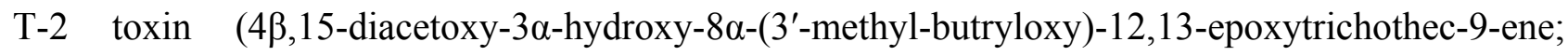
F. sporotrichioides; F. poae; F. tricinctum $)[22,217,236]$. It is frequently detected in grain products in combination with HT-2 toxin [250]. Both toxins are produced by $F$. sporotrichioides, which is generally regarded as a weak plant pathogen [251]. T-2 toxin is reported to be more toxic to animal cells than most of the other trichothecenes [252,253], and is implicated in human alimentary toxic aleukia, reported in Russia since the 19th century [22]. T-2 toxin, at $1 \mu \mathrm{g} \cdot \mathrm{mL}^{-1}$, significantly inhibited root and shoot growth (mass) of germinating wheat seedlings [239]. Germination was, however, affected only at a concentration of $100 \mu \mathrm{g} \cdot \mathrm{mL}^{-1}$. Maize callus growth was significantly inhibited from a dose of $2.15 \mu \mathrm{M}\left(=1 \mu \mathrm{g} \cdot \mathrm{mL}^{-1}\right) \mathrm{T}-2$ toxin [20]. Chang and Xue [254] had previously reported a decreased activity of wheat protoplasts exposed to 30-50 ppm T-2 toxin. Vesonder [255], using a duckweed (Lemna minor L.) bioassay, found that a doubling of the T-2 toxin concentration (3.3 to $6.7 \mu \mathrm{g} \cdot \mathrm{mL}^{-1}$ ) decreased leaf ("frond") growth rate and chlorophyll content ten-fold and 2.5-fold, respectively. At $6.7 \mu \mathrm{g} \cdot \mathrm{mL}^{-1} \mathrm{~T}-2$ toxin, growth rate of duckweed and leaf chlorophyll content were reduced to $6 \%$ and $19 \%$ of the control values, respectively. Application of T-2 toxin to onion roots resulted in a more marked decrease in the relative division rate in cells than did DON [247]. At $2.5 \mathrm{ppm}\left(2.5 \mu \mathrm{g} \cdot \mathrm{mL}^{-1}\right)$ of toxin, relative division rate for T-2 toxin was $59 \%$, while for DON, this value was $78 \%$. The mitotic index of T-2 toxin-treated onion root cells was significantly reduced from (and including) a concentration of $1 \mathrm{ppm}$. A concentration-dependent decrease in cells found in prophase and metaphase divisions was also reported [247]. 


\subsection{Moniliformin (MON)}

\subsubsection{Historical Perspective and Producing Fungal Species}

MON (1-hydroxycyclobut-1-en-3,4-dione) (Figure 11) was discovered by Cole et al. [256] while screening for toxic products of a North American isolate of $F$. moniliforme Sheldon $(F$. verticillioides [Sacc.] Nirenberg) cultured on corn. MON production has been subsequently reported for two other North American isolates [257-259] and one South African isolate of F. moniliforme [260]. The toxin has since been shown [259] to be produced also by F. moniliforme Sheldon var. subglutinans Woilenweber and Reinking (F. sacchari [Butler] W. Gams var. subglutinans [Wollenweber and Reinking] Nirenberg). These two Fusarium species are common corn pathogens in most corn producing areas of the world [261]. Rable et al. [262] have found that isolates of $F$. fusarioides obtained from millet, sorghum, peanuts, dried fish, and soil are all capable of producing MON. Nine toxic strains of $F$. avenaceum (Corda ex Fries) Sacc. isolated from barley kernels and corn tassels in Europe all produce MON, as does the one toxic strain of $F$. oxysporum Schlechtendahl isolated from barley kernels [263]. McLean et al. [22] reported that MON is produced by F. moniliforme, F. sporotrichioides, F. avenaceum, F. culmorum, F. oxysporum.

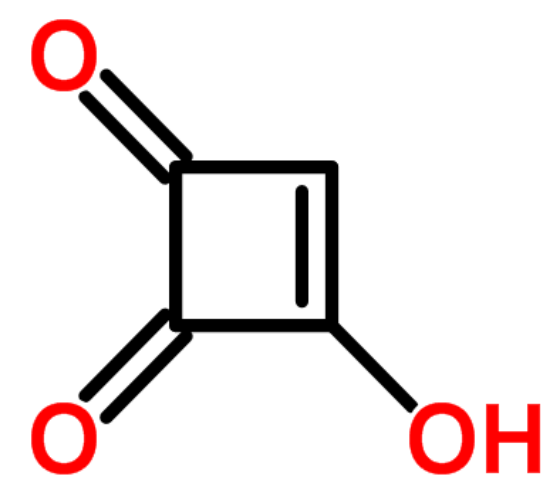

Figure 11. Chemical structure of moniliformin (MON) $\left(\mathrm{C}_{4} \mathrm{H}_{2} \mathrm{O}_{3}\right)$, taken from ChemSpider [39], 36957.

\subsubsection{Phytotoxicity and Mechanism of Action}

MON was less phytotoxic than FB1, butenolide, T-2 toxin or dihydroxyfusaric acid [255]. Wakulinski [239] reported that MON had a remarkable inhibitory effect on leaf than on root development in wheat seedling. This author further showed that $10 \mu \mathrm{g} \cdot \mathrm{mL}^{-1}$ generally resulted in a statistically significant decrease in leaf mass. Van Asch et al. [20] found that $\mathrm{MON}$ at $10 \mu \mathrm{g} \cdot \mathrm{mL}^{-1}$ and $100 \mu \mathrm{g} \cdot \mathrm{mL}^{-1}$ significantly reduced fresh mass accumulation. In L. minor, $66.7 \mu \mathrm{g} \cdot \mathrm{mL}^{-1} \mathrm{MON}$ reduced growth to $84 \%$ of the control value, while for total leaf chlorophyll content, this value was $46 \%$ [255]. The toxicity of MON has been studied under in vitro and in vivo conditions. In vitro studies indicated an inhibition of multiple enzyme systems such as pyruvate dehydrogenase, transketolase, aldose reductase, glutathione peroxidase, and glutathione reductase [264-268]. Feeding studies with different avian species such as broiler chicks and ducklings using feed contaminated with MON resulted in symptoms such as acidosis and muscular weakness [269,270]. 


\subsection{Fumonisin B1 (FB1)}

\subsubsection{Historical Perspective and Producing Fungal Species}

Fumonisins are produced by certain Fusarium spp. including F. verticillioides (Sacc.) Nirenberg, F. proliferatum (Matsushima) Nirenberg and F. nygamai Burgess and Trimboli [271,272]. FB1 (Figure 12) first isolated from F. moniliforme MRC 826 by Gelderblom et al. [273], is a hydroxylated long chain alkylamine with two tricarboxylic acid moieties attached. FB1 is responsible for several diseases: leukoencephalomalacia in horses [274]; pulmonary oedema and hydrothorax in pigs [275] and liver cancer in rats [273]. In addition, it has been implicated as an aetiological agent in human oesophageal cancer in certain regions of South Africa [276] and China [277].

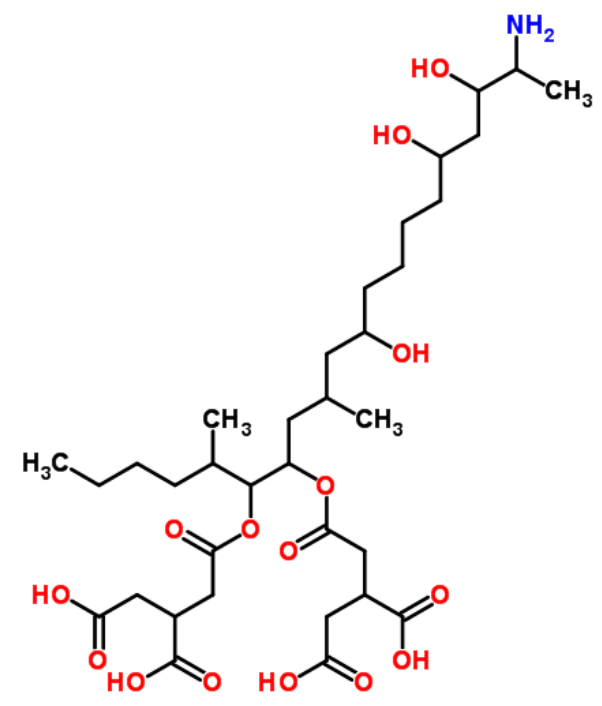

Figure 12. Chemical structure of fumonisin B1 (FB1) $\left(\mathrm{C}_{34} \mathrm{H}_{59} \mathrm{NO}_{15}\right)$, taken from ChemSpider [39], 3313.

\subsubsection{Phytotoxicity}

FB1 is known to exhibit phytotoxic effects towards different plants, including economically important crops [20,233,278-280]. Previous studies on other legume crops showed that soybeans (Glycine $\max \mathrm{L}$.) were severely damaged (necrosis and wilting) when sprayed with a $1000 \mu \mathrm{g} \cdot \mathrm{mL}^{-1}$ concentration of FB1 [281]. Doehlert et al. [282] showed that the presence of high levels of fumonisins in maize seeds might have deleterious effects on seedling emergence. An inhibitory effect on root elongation in germinating maize seedlings following FB1 treatment has been reported [282]. In maize and tomato seedlings, the fumonisins reduced root and shoot length and dry mass in a dose-dependent manner, and in a detached leaf assay, fumonisin application caused necrotic patches [280]. In comparing the fumonsins with AAL-toxin (TA, a host-specific pathotoxin of Alternaria alternata (Fr.:Fr.) Keissl. f. sp. Lycopersici causes stem canker disease of tomato) toxin, FB1 was found to be the most phytotoxic, especially in AAL-sensitive genotypes of tomato [280]. Several symptoms (chlorosis, necrosis, black leaf lesions, tissue curl, stunting, defoliation and death) developed, when FB1 was sprayed onto leaves of plantlets of a number of weed and crop plants, and the severity of which was varied with toxin concentration and plant species [281]. FB1 was implicated as an 
aetiological agent in disease development since the response of jimsonweed plants treated with ground autoclaved fungal material was similar to symptoms (soft rot along leaf veins) caused by FBI application [278].

\subsubsection{Mechanism of Action}

When plants are contaminated by fumonisins, they could cause physiological damage, growth inhibition, and death in plants [283]. When the grains are infected, the starch granules of the endosperm are extensively degraded (pitted) [284] and the storage protein matrix that surround the starch granules were absent [285]. The germinability of bean, red gram, green gram and black gram seeds had vigorously reduced when soaked on culture filtrate of the toxic fungal strain [286]. Amylase production in the endosperm (specifically low pI amylases) was inhibited, suggesting that FB1 may interfere metabolically with germination [282]. FBl-treated maize callus cells exhibited dose-dependent deteriorative alterations in cell ultrastructure, which included cell wall thickening, the accumulation of what is presumed to be phenolics within vacuoles and the accumulation of large starch grains within swollen plastid [287]. The presence of extensive starch grains may reflect an interference with starch metabolism in the plant cell, as reported by Doehlert et al. [282]. FB1 was found to cause electrolyte leakage, photobleaching and a decrease in chlorophyll content [288]. The electrolyte leakage may be explained by the known membrane disruption effects of FB1 [289], while the photobleaching may arise from chloroplast membrane disruption that may inhibit photosynthesis, resulting in photobleaching of pigments or the photobleaching may be arise from accumulation of the inhibitory photodynamic metabolic intermediates [289].

\subsection{Fusarins and Fusaric Acid (FA)}

\subsubsection{Historical Perspective and Producing Fungal Species}

Fusarins are polyketides produced by many Fusarium species and by the entomopathogenic fungus Metarhizium anisopliae [290]. Fusarin A, B, C, and D were first described in 1981 by Wiebe and Bjeldanes in Berkeley, California [291]. The same authors already had isolated and partially characterized fusarin C [291], and its chemical structure was completed in 1984 [292]. The structure of fusarin C consists of a polyenic chromophore with a substituted 2-pyrrolidone (Figure 13a) [292]. Two other related compounds, fusarin A and D, with similar UV absorption properties were produced by Fusarium. A third kind of fusarin-like molecule was isolated from F. moniliforme, which was called fusarin F. [293]. Kleigrewe et al. found out that this published structural assignment of fusarin $\mathrm{F}$ is incorrect, since fusarin C epimerizes to epi-fusarin C via the open-chain fusarin C structure [294]. Furthermore they discovered a new fusarin C-like structure called dihydrofusarin $\mathrm{C}$.

FA (Figure 13b) was probably the first of the fungal toxins implicated in plant disease. In 1934, Yabuta, a Japanese agricultural chemist, was trying to isolate gibberellins when he separated a crystalline compound from the culture filtrate of Gibberella fujikuroi [295]. At that time the fungus was classified as $F$. heterosporum Nees. This compound was named FA and its chemical structure was 5-butylpicolic acid. The production of FA is broadly distributed among the entire genus Fusarium. Not only members of the Gibberella fujikuroi species complex (GFC), e.g., F. fujikuroi, F. proliferatum, 
$F$. circinatum, $F$. mangiferae, $F$. verticillioides, and $F$. subglutinans but also more distantly related Fusarium species, such as $F$. crookwellense, F. heterosporum, F. napiforme, F. oxysporum, and F. solani are producers of FA [295-298].

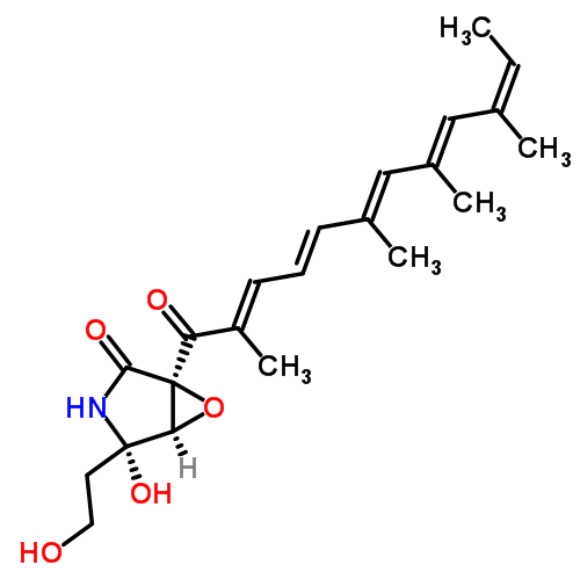

(a)

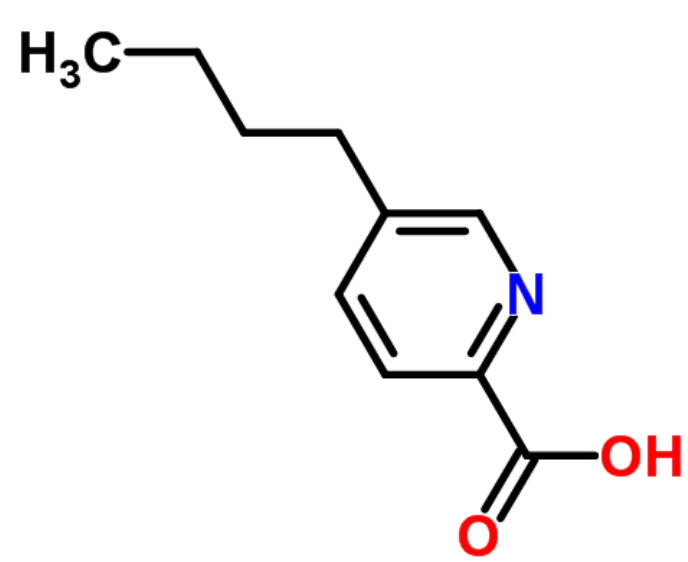

(b)

Figure 13. Chemical structure of (a) fusarin, taken from ChemSpider [39], 13085526; and (b) fusaric acid (FA), taken from ChemSpider [39], 3324.

\subsubsection{Phytotoxicity and Mechanism of Action}

Little is known about the phytotoxicity of the fusarins [22]. F. moniliforme was found to produce fusarin $\mathrm{C}$ on 7 varieties of maize, and on soybean, wheat, rye and barley [299]. In Taiwan, 83\% of Fusarium isolates from maize were capable of producing fusarin C [300]. FA was one of the first fungal metabolites implicated in plant pathogenesis, in concrete in the tomato wilt symptoms caused by F. oxysporum f. sp. lycopersici Schlecht. emend. Snyd. and Hans [301]. Phytotoxicity assays with FA and picolinic acid analogs revealed that the addition of alkyl groups to the 5-position of picolinic acid increased their phytotoxicity [302]. The toxic effects of FA on plants include alteration of membrane permeability (modification of cell membrane potential), decrease of mitochondrial activity and oxygen uptake, inhibition of ATP synthesis and inhibition of root growth [303-306]. These effects are observed at toxic concentrations $\left(>10^{-5} \mathrm{M}\right)$. Nontoxic concentrations $\left(<10^{-6} \mathrm{M}\right)$ of FA induce synthesis of the phytoalexin camalexin, which induces the formation of ROS and increases cytosolic $\mathrm{Ca}^{2+}$. It has been suggested that FA could act as an elicitor of plant responses to pathogen attack [306]. The concentration of FA is positively correlated with Fusarium wilt index [307]. Infected plants had reduced stomata conductance and transpiration rate, which resulted in lower levels of water loss than in control plants [307]. 


\subsection{Zearalenone (ZEA)}

\subsubsection{Historical Perspective}

ZEA, also known as F-2 toxin (6-(10-hydroxy-6-oxo-trans-1-undecenyl)- $\beta$-resorcyclic acid- $\mu$-lactone) (Figure 14) is an estrogenic mycotoxin [308]. This mycotoxin causes hyperestrogenism, especially in swine [309]. The first report of moldy corn causing an estrogenic disturbance among swine appeared in 1928 [310]. Since then, other reports have come from the United States [311-313], Australia [314], and Ireland [315]. In 1962, Stob et al. [316] demonstrated that an anabolic uterotrophic compound, crystallized and partially characterized by them, was produced by Gibberella zeae, the perfect stage of Fusarium graminearum (F. roseum "Graminearum"). Urry et al. [317] determined its chemical structure and named it ZEA. Partial characterization of the compound and environmental conditions suitable for its production were reported by workers at the University of Minnesota [313,318], who referred to ZEA as F-2.

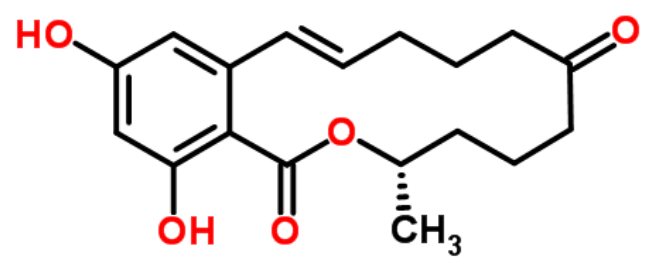

Figure 14. Chemical structure of zearalenone (ZEA) $\left(\mathrm{C}_{18} \mathrm{H}_{22} \mathrm{O} 5\right)$, taken from ChemSpider [39], 44448977.

\subsubsection{Producing Fungal Species}

Fungi-producing ZEA contaminate corn and also colonize, to a lesser extent, barley, oats, wheat, sorghum, millet and rice. In addition, the toxin has been detected in cereals products like flour, malt, soybeans and beer. Fungi of the genus Fusarium infect cereals in the field. Toxin production mainly takes place before harvesting, but may also occurs post-harvest if the crop is not handled and dried properly [319]. ZEA is produced by a variety of Fusarium fungi, including F. graminearum, $F$. culmorum, F. cerealis, F. equiseti, F. crookwellense and F. semitectum, which are common soil fungi, in temperate and warm countries, and are regular contaminants of cereal crops worldwide [3].

\subsubsection{Phytotoxicity and Mechanism of Action}

ZEA has a less phytotoxicity. It was the least toxic of six metabolites to three varieties of wheat seedlings [239], where at $100 \mu \mathrm{g} \cdot \mathrm{mL}^{-1}$, ZEA did not significantly affect germination or the subsequent root and leaf development. Germinating caryopses of rye, wheat, triticale and field bean were found to

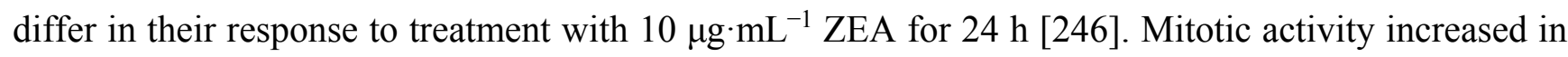
rye, but decreased in wheat and field bean. No abnormal metaphase chromosomes were observed [246]. ZEA at $5 \mu \mathrm{g} \cdot \mathrm{mL}^{-1}$, had an inhibitory effect on root and shoot elongation and fresh mass accumulation of germinating, excised embryos of $Z$. mays. Interestingly, 10 and $25 \mu \mathrm{g} \cdot \mathrm{mL}^{-1} \mathrm{ZEA}$ stimulated these parameters measured [146]. When DON and ZEA were applied simultaneously, to give a final 
combined toxin concentration of $25 \mu \mathrm{g} \cdot \mathrm{mL}^{-1}$, the inhibitory effects on root and shoot elongation and mass were similar to or exceeded the values measured for DON alone. This would suggest an additive and possibly a synergistic effect when ZEA and DON occur in combination [146]. In a study [320] to investigate the fate of ZEA in plant tissue, ZEA was found to be metabolized by $Z$. mays cell suspensions to the $\alpha$ - and $\beta$-zearalenol and the $\beta$-D-glucosides of ZEA and $\alpha$ - and $\beta$-zearalenol. This study showed that up to $50 \%$ of the mycotoxin became bound to starch, hemicellulose, and in particular, lignin fractions, suggesting binding of ZEA metabolites to cell wall components.

\section{Remarks on the Phytotoxic Properties of Mycotoxins}

After reviewing the literature on phytotoxicity of mycotoxins, several points can be drawn. Mycotoxins differ in structure which explains the great variation of disease symptoms and biological activities induced on plant cells and seed germination. Mycotoxins can cause these adverse toxicities in different seedlings and plants varities. The resulting phytotoxic properties are dose-related and differ from a mycotoxin to another. Table 2 summarizes selected reports of mycotoxins with potentially phytotoxic properties at several doses (for comparison). The phytotoxic properties of mycotoxins varied from their role in causing plant diseases (wilt, necrosis, chlorosis, curling, browning, and lesions induction) to their inhibitory effect on seedling germination parameters. For all toxins, the inhibitory effects were generally more marked for root paramters than for shoot elongation or mass $[46,146]$.

Table 2. Summary of the phytotoxic properties of mycotoxins and their effective doses on plants.

\begin{tabular}{|c|c|c|c|c|}
\hline Mycotoxin & Dose & Affected Plants & Phytotoxic Effects & Ref. \\
\hline \multirow{4}{*}{ Aflatoxin } & $>10 \mu \mathrm{g} \cdot \mathrm{mL}^{-1}$ & Lepidium sativum & $\begin{array}{l}\text { Maximal reduction in the growth rate of } \\
\text { hypocotyls after germination }\end{array}$ & [40] \\
\hline & $0.83 \mu \mathrm{g} \cdot \mathrm{mL}^{-1}$ & Barley & LD 50 seedling viability & {$[47]$} \\
\hline & $1.74 \mu \mathrm{g} \cdot \mathrm{mL}^{-1}$ & Wheat & LD50 seedling viability & {$[47]$} \\
\hline & $2.75 \mu \mathrm{g} \cdot \mathrm{mL}^{-1}$ & Sorghum & LD50 seedling viability & {$[47]$} \\
\hline CTN & $10^{-3}-10^{-4} \mathrm{M}$ & Bean, cotton, sorghum & Symptoms of wilting & {$[63]$} \\
\hline \multirow[b]{2}{*}{ PAT } & $25 \mu \mathrm{g} \cdot \mathrm{mL}^{-1}$ & Maize & $5 \%$ inhibition of radicle emergence & {$[17]$} \\
\hline & $100 \mu \mathrm{g} \cdot \mathrm{mL}^{-1}$ & Wheat & $\begin{array}{l}\text { Decreases in internodal elongation, floret } \\
\text { number, seed weight, and seed number }\end{array}$ & {$[96]$} \\
\hline \multirow{3}{*}{ PA } & $250-500 \mu \mathrm{g} \cdot \mathrm{mL}^{-1}$ & Picea glehnii & $\begin{array}{c}\text { Browning of Picea glehnii roots } \\
\text { without root destruction }\end{array}$ & {$[16]$} \\
\hline & & Lettuce & Growth inhibition of lettuce seedlings & {$[16]$} \\
\hline & $500 \mu \mathrm{g} \cdot \mathrm{mL}^{-1}$ & Corn & Growth of the main root was reduced $50 \%$ & {$[18]$} \\
\hline \multirow[t]{2}{*}{ OTA } & $1-2 \mathrm{mM}$ & Arabidopsis thaliana & $\begin{array}{c}\text { Formation of macroscopic lesions on } \\
\text { leaves within } 1-2 \text { days. }\end{array}$ & {$[144]$} \\
\hline & $50 \mu \mathrm{M}$ & Arabidopsis thaliana & Blocking of root elongation & {$[145]$} \\
\hline \multirow{3}{*}{ TA } & $0.12 \mathrm{mM}$ & Rice & Leaf browning and $80 \%$ root growth inhibition & {$[161]$} \\
\hline & $100 \mu \mathrm{g} \cdot \mathrm{mL}^{-1}$ & $\begin{array}{l}\text { Datura innoxia, rye, wheat, } \\
\text { lettuce and green gram }\end{array}$ & Growth inhibition of germinating seeds & {$[160]$} \\
\hline & $200 \mu \mathrm{g} \cdot \mathrm{mL}^{-1}$ & Datura innoxia & $\begin{array}{l}\text { Localized chlorotic spots turned } \\
\text { into necrotic after } 24 \mathrm{~h}\end{array}$ & {$[160]$} \\
\hline
\end{tabular}


Table 2. Cont.

\begin{tabular}{|c|c|c|c|c|}
\hline $\mathrm{CB}$ & $10^{-3} \mathrm{M}$ & Bromus tectorum & $\begin{array}{l}\text { Coleoptile elongation reduction to } \\
34 \% \text { of the control }\end{array}$ & [203] \\
\hline \multirow{2}{*}{$\mathrm{CE}$} & $5 \mathrm{ppm}$ & Apple & Limpness of shoot & [197] \\
\hline & $10^{-4} \mathrm{M}$ & Striga hermonthica & $\mathrm{LD}_{50}$ seedling viability & [199] \\
\hline Pyrenophoric acid & $10^{-3} \mathrm{M}$ & Cheatgrass & $\begin{array}{l}\text { Coleoptile length reduction relative to the } \\
\text { control by approximately half }\end{array}$ & [202] \\
\hline Pyrichalasin $\mathrm{H}$ & $1 \mu \mathrm{g} \cdot \mathrm{mL}^{-1}$ & Rice & Characteristic curling of the shoot & [204] \\
\hline Zygosporin D & $1 \mathrm{nmol} /$ plant & Rice & $\begin{array}{l}\text { Reduction of the second leaf sheath length of } \\
\text { treated plants to } 41 \% \text { of control }\end{array}$ & [205] \\
\hline \multirow{5}{*}{ DON } & $2 \mu \mathrm{g} \cdot \mathrm{mL}^{-1}$ & Wheat & $50 \%$ inhibition of root growth & [241] \\
\hline & $10 \mu \mathrm{g} \cdot \mathrm{mL}^{-1}$ & Wheat & $50 \%$ inhibition of shoot growth & {$[241]$} \\
\hline & $50 \mu \mathrm{g} \cdot \mathrm{mL}^{-1}$ & Wheat & Complete inhibition of germination & {$[244]$} \\
\hline & $10-25 \mu \mathrm{g} \cdot \mathrm{mL}^{-1}$ & Wheat & Plantlet growth reduction & [244] \\
\hline & 10 and $25 \mu \mathrm{g} \cdot \mathrm{mL}^{-1}$ & Maize & $\begin{array}{l}\text { Significant inhibition of both primary root and } \\
\text { shoot elongation of germinating embryos }\end{array}$ & [246] \\
\hline \multirow{2}{*}{ NIV } & $48 \mu \mathrm{g} \cdot \mathrm{mL}^{-1}$ & Wheat & $50 \%$ inhibition of root growth & [241] \\
\hline & $100 \mu \mathrm{g} \cdot \mathrm{mL}^{-1}$ & Wheat & $50 \%$ inhibition of shoot growth & [241] \\
\hline \multirow{3}{*}{ DAS } & $1.26 \mu \mathrm{g} \cdot \mathrm{mL}^{-1}$ & Barley & $\mathrm{LD}_{50}$ seedling viability & {$[47]$} \\
\hline & $3.98 \mu \mathrm{g} \cdot \mathrm{mL}^{-1}$ & Wheat & $\mathrm{LD}_{50}$ seedling viability & [47] \\
\hline & $10 \mu \mathrm{g} \cdot \mathrm{mL}^{-1}$ & Sorghum & $\mathrm{LD}_{50}$ seedling viability & {$[47]$} \\
\hline \multirow{3}{*}{$\mathrm{T}-2$ toxin } & $1 \mu \mathrm{g} \cdot \mathrm{mL}^{-1}$ & Wheat & $\begin{array}{l}\text { Significant inhibition of root and shoot growth } \\
\text { of germinating seedlings }\end{array}$ & [239] \\
\hline & $1 \mu \mathrm{g} \cdot \mathrm{mL}^{-1}$ & Maize & Significant inhibition of callus growth & {$[20]$} \\
\hline & $6.7 \mu \mathrm{g} \cdot \mathrm{mL}^{-1}$ & Duckweed (Lemna minor L.) & Decrease of leaf growth rate & {$[255]$} \\
\hline \multirow{3}{*}{ MON } & $10 \mu \mathrm{g} \cdot \mathrm{mL}^{-1}$ & Wheat & A significant decrease in leaf mass & {$[239]$} \\
\hline & $10-100 \mu \mathrm{g} \cdot \mathrm{mL}^{-1}$ & Maize & $\begin{array}{l}\text { Significant reduction in fresh mass } \\
\text { accumulation }\end{array}$ & {$[20]$} \\
\hline & $66.7 \mu \mathrm{g} \cdot \mathrm{mL}^{-1}$ & Duckweed (L. minor L.) & Growth reduction to $84 \%$ of the control & [255] \\
\hline \multirow{4}{*}{ FB1 } & $1000 \mu \mathrm{g} \cdot \mathrm{mL}^{-1}$ & Soybeans (Glycine max L.) & Necrosis and wilting & [281] \\
\hline & $100 \mathrm{ppm}$ & Maize & Radicle elongation inhibition & [282] \\
\hline & $1-100 \mu \mathrm{M}$ & Tomato & Leaves necrosis & [280] \\
\hline & $10-200 \mu \mathrm{g} \cdot \mathrm{mL}^{-1}$ & Jimsonweed & $\begin{array}{c}\text { Chlorosis and necrosis and reduction in } \\
\text { height and biomass }\end{array}$ & [281] \\
\hline \multirow[b]{2}{*}{ FA } & $10^{-3} \mathrm{M}$ & Tomato & Symptoms of wilting & [301] \\
\hline & $10^{-5} \mathrm{M}$ & Arabidopsis thaliana & $\begin{array}{l}\text { Toxic effects such as alteration of cell } \\
\text { growth, mitochondrial activity and } \\
\text { membrane permeability }\end{array}$ & [306] \\
\hline ZEA & $5 \mu \mathrm{g} \cdot \mathrm{mL}^{-1}$ & Maize & $\begin{array}{l}\text { Inhibitory effect on root and shoot elongation } \\
\text { and fresh mass accumulation of } \\
\text { germinating, embryos }\end{array}$ & [146] \\
\hline
\end{tabular}

\section{Conclusions}

This review gives a comprehensive overview of the current knowledge on the phytotoxic effect of mycotoxins. Data about historical perspective and producing fungal species of each mycotoxin class 
were also covered. Most mycotoxins of concern are produced by three genera of fungi, namely, Aspergillus, Penicillium, and Fusarium in addition to dematiaceous fungal genera (Alternaria, Helminthosporium, Drechslera, Phoma, Zygosporium). The major mycotoxin-producing fungi are not aggressive pathogens in plants; however, mycotoxins are produced by several genera in plants during the growing season when portals of entry are provided and environmental conditions are appropriate. Toxigenic fungi in crops are divided into those which invade and produce their toxins before harvest which are often rather loosely called "field fungi" and those which becomes a problem after harvest "storage fungi". Invasion by fungi before harvest is governed primarily by plant host-fungus and other biological interactions (e.g., insects), while growth by fungi postharvest is governed by crop (nutrients), physical (temperature, moisture) and biotic factors (insects, competition) factors. However, the original source of the fungi in both circumstances is the field. Within the genus Aspergillus, the major class of mycotoxins, are the aflatoxins. A. flavus is a common contaminant in agriculture, can infect crops prior to harvesting causing hazardous to the plant's growth and development as well as to the consumer's health since aflatoxin-infected crops have from time to time been returned to agricultural soils. Penicillium spp. are more typically associated with storage of crops and the production of mycotoxins such as CTN, PAT, PA, and OTA. Ochratoxin usually is formed in storage or during drying of certain commodities for processing. Within the genus Fusarium, there are a number of important mycotoxin-producing species. Some important plant pathogens are in this genus and are causes of wilts and scab or blight diseases of small grains. Ear rot also can be caused by Fusarium spp. F. graminearum is the major causative agent; however, other species such as $F$. verticillioides, $F$. proliferatum, $F$. culmorum, $F$. sporotrichioides, $F$. moniliforme and F. subglutinans may cause ear rot. These latter agents may produce DON, NIV, DAS, T-2 toxin, MON, FB1, fusarin C, FA and ZEA during the pathogenic state in different varieties of agriculture crops. Understanding the mechanisms of mycotoxin action on the host plants at the cellular and biochemical level is important in the overall goal to inhibit or decrease the action of mycotoxins.

\section{Acknowledgments}

This work was financially supported by a research grant from the Deutsche Forschungsgemeinschaft, Bonn, Germany (PA 764/19-1, AOBJ 618653).

\section{Author Contributions}

Most of the text was written by Ahmed A. Ismaiel, smaller contributions to all parts were done by Jutta Papenbrock.

\section{Conflicts of Interest}

The authors declare no conflict of interest.

\section{References}

1. Bennett, J.W. Mycotoxins, mycotoxicoses, mycotoxicology and mycopathologia. Mycopathologia 1987, 100,3-5. 
2. Bennett, J.W.; Bentley, R. What's in a name? Microbial secondary metabolism. Adv. Appl. Microbiol. 1989, 34, 1-28.

3. Bennett, J.W.; Klich, M. Mycotoxins. Clin. Microbiol. Rev. 2003, 16, 497-516.

4. Legan, J.D. Cereals and cereal products. In The Microbiological Safety and Quality of Food; Lund, B.M., Baird-Parker, T.C., Gould, G.W., Eds.; Aspen Publishers Inc.: Gaithersburg, MD, USA, 2000; pp. 759-783.

5. Miller, J.D. Fungi and mycotoxins in grain: Implications for stored product research. J. Stored Prod. Res. 1995, 31, 1-16.

6. Lillehoj, E.B.; Zuber, M.S. Aflatoxin problem in corn and possible solutions. In Proceedings of the 30th Annual Corn and Sorghum Research Conference, Chicago, IL, USA, 1975; pp. 230-250. Available online: http://naldc.nal.usda.gov/naldc/download.xhtml?id=29471\& content=PDF (accessed on 21 July 2015).

7. Llewellyn, G.C.; O’Donnell, W.A.; Dashek, W.V. Aflatoxin infuences on seed germination and root elongation by two cultivars of Glycine $\max$ and uptake of ${ }^{65} \mathrm{Zn}^{-\mathrm{ZnCl}_{2}}$ by the cultivars. Mycopathologia 1984, 86, 129-136.

8. McLean, M.; Berjak, P.; Watt, M.P.; Dutton, M.F. The effects of aflatoxin B1 on immature germinating maize (Zea mays) embryos. Mycopathologia 1992, 119, 181-190.

9. Anderson, H.W.; Nehring, E.W.; Wichser, W.R. Aflatoxin contamination of corn in the field. J. Agr. Food Chem. 1975, 23, 775-782.

10. Mertz, D.; Lee, D.; Zuber, M.; Lillehoj, E. Uptake and metabolism of aflatoxin by Zea mays. J. Agric. Food Chem. 1980, 28, 963-966.

11. Frisvad, J.C.; Filtenborg, O. Classification of terverticillate penicillia based on profiles of mycotoxins and other secondary metabolites. Appl. Environ. Microbiol. 1983, 46, 1301-1310.

12. Frisvad, J.C.; Thrane, U. Mycotoxin production by food borne fungi. In Introduction to Food-Borne Fungi; Samson, R.A., Hoekstra, E.S., Frisvad, J.C., Filtenborg, O., Eds.; Centraalbureau Voor Schimmelcultures: Baarn, The Netherlands, 1996; pp. 251-260.

13. Müller, H.M.; Amend, R. Formation and disappearance of mycophenolic acid, patulin, penicillic acid and PR toxin in maize silage inoculated with Penicillium roqueforti. Arch. Tierernahr. 1997, 50, 213-225.

14. Frisvad, J.C.; Samson, R.A. Polyphasic taxonomy of Penicillium subgenus Penicillium. A guide to identification of food and air-borne terverticillate Penicillia and their mycotoxins. Stud. Mycol. 2004, 49, 1-174.

15. Yamaji, K.; Fukushi, Y.; Hashidoko, Y.; Yoshida, T.; Tahara, S. Characterization of antifungal metabolites produced by Penicillium species isolated from seeds of Picea glehnii. J. Chem. Ecol. 1999, 25, 1643-1654.

16. Yamaji, K.; Fukushi, Y.; Hashidoko, Y.; Tahara, S. Penicillium frequentans from Picea glehnii seedling roots as a possible biological control agent against damping-off. Ecol. Res. 2005, 20, $103-107$.

17. Ismaiel, A.A.; Papenbrock, J. The effects of patulin from Penicillium vulpinum on seedling growth, root tip ultrastructure and glutathione content of maize. Eur. J. Plant Pathol. 2014, 139, 497-509. 
18. Keromnes, J.; Thouvenot, D. Role of penicillic acid in the phytotoxicity of Penicillium cyclopium and Penicillium canescens to the germination of corn seeds. Appl. Environ. Microbiol. 1985, 49, 660-663.

19. Koteswara Rao, V.; Girisham, S.; Reddy, S.M. Influence of different species of Penicillium and their culture filtrates on seed germination and seedling growth of sorghum. J. Biochem. Technol. 2014, 5, 832-837.

20. Van Asch, M.A.J.; Rijkenberg, F.H.F.; Coutinho, T.A. Phytotoxicity of fumonisin B1, moniliformin and T-2 toxin in corn callus cultures. Phytopathology 1992, 82, 1330-1332.

21. Nelson, E.P.; Dignani, M.C.; Anaissie, E.J. Taxonomy, biology, and clinical aspects of Fusarium species. Clin. Microbiol. Rev. 1994, 7, 479-504.

22. McLean, M. The phytotoxicity of Fusarium metabolites: An update since 1989. Mycopathologia 1996, 133, 163-179.

23. Desjardins, A.E.; Hohn, T.M. Mycotoxins in plant pathogenesis. Mol. Plant-Microbe Interact. 1997, 10, 147-152.

24. Kühl, H. Pharmazeutische Zentrahalle. für Deutschland. In Historical Aspects of Mycotoxicology and Developments in Aflatoxins, Proceedings of the International Symposium on Mycotoxins, Cairo, Egypt, 6-8 September 1981; Mirocha, C.J., Ed.; Food and Drug Administration: RockVille, MD, USA; National Research Center: Cairo, Egypt, 1983.

25. Blount, W.P. Turkey X Disease. J. Br. Turkey Fed. 1961, 9, 52-61.

26. Asplin, F.D.; Carnaghan, R.B.A. The toxicity of certain groundnut meals for poultry with special reference to their effect on ducklings and chickens. Vet. Rec. 1961, 73, 1215-1218.

27. Sargeant, K.; O'Kelly, J.; Carnaghan, R.B.A.; Alleroft, R. The assay of a toxic principle in certain groundnut meals. Vet. Rec. 1961, 73, 1219-1222.

28. Sargeant, K.; Sheridan, A.; O’Kelly, J.; Carnaghan, R.B.A. Toxicity associated with certain samples of groundnuts. Nature 1961, 192, 1096-1097.

29. Sargeant, K.; Carnaghan, R.B.A.; Alleroft, R. Toxic products in Groundnuts: Chemistry and Origin. Chem. Ind. 1963, 31, 53-55.

30. Asao, T.; Buchi, G.; Abdel Kader, M.M.; Chang, S.B.; Wick, E.; Wogan, G.N. Aflatoxins A and G. J. Amer. Chem. Soc. 1963, 85, 1706-1707.

31. Richard, J.L.; Payne, G.A.; Desjardin, A.E.; Maragos, C.; Norred, W.P.; Pestka, J.J. Mycotoxins, risks in plant, animal and human systems. In CAST Task Force Report 139; Council for Agricultural Science and Technology: Ames, IA, USA, 2003; pp. 101-103.

32. Ismaiel, A.A.; Tharwat, N.A. Antifungal activity of silver ion on ultrastructure and production aflatoxin B1 and patulin by two mycotoxigenic strains, Aspergillus flavus OC1 and Penicillium vulpinum CM1. J. Mycol. Méd. 2014, 24, 193-204.

33. Chipley, J.R.; Uraih, N. Inhibition of Aspergillus growth and aflatoxin release by derivatives of benzoic acid. Appl. Environ. Microbiol. 1980, 40, 352-357.

34. Paranagama, P.A.; Abeysekera, K.H.T.; Abeywickrama, K.; Nugaliyadde, L. Fungicidal and anti-aflatoxigenic effects of the essential oil of Cymbopogon citratus (DC.) Stapf. (lemongrass) against Aspergillus flavus Link. isolated from stored rice. Lett. Appl. Microbiol. 2003, 37, 86-90. 
35. Krishnamurthy, Y.L.; Shashikala, J. Inhibition of aflatoxin B1 production of Aspergillus flavus, isolated from soybean seeds by certain natural plant products. Lett. Appl. Microbiol. 2006, 43, 469-474.

36. Gnonlonfin, G.J.B.; Adjovi, Y.; Gbaguidi, F.; Gbenou, J.; Katerere, D.; Brimer, L.; Sanni, A. Scopoletin in cassava products as an inhibitor of aflatoxin production. J. Food Saf. 2011, 4, 553-558.

37. Ismaiel, A.A.; Ghaly, M.F.; El-Naggar, A.K. Milk kefir: Ultrastructure, antimicrobial activity, and efficacy on aflatoxin B1 production by Aspergillus flavus. Curr. Microbiol. 2011, 62, 1602-1609.

38. Pratiwi C.; Rahayu, W.P.; Lioe, H.N.; Herawati, D.; Broto, W.; Ambarwati, S. The effect of temperature and relative humidity for Aspergillus flavus BIO 2237 growth and aflatoxin production on soybeans. Int. Food Res. J. 2015, 22, 82-87.

39. ChemSpider. Available online: http://www.chemspider.com (accessed on 13 July 2015).

40. Crisan, E.V. Effects of aflatoxin on seedling growth and ultrastructure in plants. Appl. Microbiol. 1973, 12, 991-1000.

41. Sinha, K.K.; Kumari, P. Some physiological abnormalities induced by aflatoxin B1 in mung seeds (Vigna radiata var. Pusa Baishakhi). Mycopathologica 1990, 110, 77-79.

42. Sinha, K.S.; Sinha, A.K. Effect of aflatoxin B1 on germination index and seedling growth in wheat varieties. Mycopathologica 1993, 123, 165-169.

43. Adekunle, A.A.; Bassir, O. The effects of afatoxinB1 and G1 on the germination and leaf colour of cowpea (Vigna sinensis). In Mycopathologia et Mycologia Applicata; Klower Academic Publisher: Ibadan, Nigeria, 1997; pp. 1-12.

44. Samuel, A.T.; Valentine, I.T. Effect of total aflatoxin on the growth characteristics and chlorophyll level of sesame (Sesamum indicum L.). N. Y. Sci. J. 2014, 7, 8-13.

45. Reiss, J. Effects of mycotoxins on higher plants, algae, fungi and bacteria. In Mycotoxic Fungi, Mycotoxins, Mycotoxicoses: An Encyclopaedic Handbook Volume 3. Mycotoxicoses of Man and Plants: Mycotoxin Control and Regulatory Practices; Wyllie, T.D., Morehouse, L.G., Eds.; Marcel Dekker Inc.: New York, NY, USA, 1978; pp. 119-143.

46. McLean, M.; Watt, M.P.; Berjak, P.; Dutton, M.F. Aflatoxin B1-Its effects on an in vitro plant system. Food Addit. Contam. 1995, 12, 435-443.

47. Hasan, H.A.H. Phytotoxicity of pathogenic fungi and their mycotoxins to cereal seedling viability. Mycopathologia 1999, 148, 149-155.

48. Fadl-Allah, E.M.; Mahmoud, M.A.-H.; Abd El-Twab, M.H.; Helmey, R.K. Aflatoxin B1 induces chromosomal aberrations and 5S rDNA alterations in durum wheat. J. Assoc. Arab Univ. Basic Appl. Sci. 2011, 10, 8-14.

49. Slowatizky, I.; Mayer, A.M.; Plojakoff-Mayber, A. The effect of aflatoxin on greening of etiolated leaves. Isr. J. Bot. 1969, 18, 31-36.

50. Tripathi, R.K.; Misra, R.S. Mechanism of inhibition of maize seed germination by aflatoxin BI. In Mycotoxins in Food and Feed. Bilgrami, K.S., Prasad, T., Sinha, K.K., Eds.; Allied Press: Bhagalpur, India, 1983, pp. 129-141. 
51. McLean, M.; Watt, M.P.; Berjak, P.; Dutton, M.F.; Snyman, C. Immunocytochemical localisation of aflatoxin B1: A preliminary investigation. Commun. Electron Microsc. Soc. South. Afr. 1992, 22, 73-74.

52. Vogelstein, B.; Kinzler, K.W. P53 function and dysfunction. Cell 1992, 70, 523-526.

53. Lane, D.P. P53, guardian of the genome. Nature 1992, 358, 15-16.

54. Symonds, H.; Krall, L.; Remington, L.; Saenz-Robles, M.; Lowe, S.; Jacks, T.; van Dyke, T. P53 dependency apoptosis suppresses tumor growth and progression in vivo. Cell 1994, 78, 703-711.

55. Hetherington, A.C.; Raistrick, H. Studies in the Biochemistry of Micro-organisms. On the production and chemical constitution of a new yellow colouring matter, citrinin, produced from glucose by Penicillium citrinum. Trans. Roy. Soc. (Lond.) B 1931, 220, 269-295.

56. Ciegler, A.; Vesonder, R.F.; Jackson, L.K. Production and biological activity of patulin and citrinin from Penicillium expansum. Appl. Environ. Microbiol. 1977, 33, 1004-1006.

57. Bragulat, M.R.; Martinez, E.; Castella, G.; Cabanes, F.J. Ochratoxin A and citrinin producing species of the genus Penicillium from feedstuffs. Int. J. Food Microbiol. 2008, 126, 43-48.

58. Nelson, T.S.; Kirby, L.K.; Beasley, J.N.; Johnson, Z.B.; Ciegler, A. The effect of drying method and storage time on citrinin activity in corn. Poult. Sci. 1985, 64, 464-468.

59. Scott, P.M.; van Walbeek, W.; Kennedy, B.; Anyeti, B. Mycotoxins (ochratoxin A, citrinin and sterigmatocystin) and toxigenic fungi in grains and other agricultural products. J. Agric. Food Chem. 1972, 20, 1103-1109.

60. Tanaka, K.; Sago, Y.; Zheng, Y.; Nakagawa, H.; Kushiro, M. Mycotoxins in rice. Int. J. Food Microbiol. 2007, 119, 59-66.

61. Vella, F.; Kpodo, K.; Sorensen, A.K.; Jakobsen, M. The occurrence of mycotoxins in fermented maize products. Food Chem. 1995, 56, 147-153.

62. White, A.G.; Truelove, B. The effects of aflatoxin B1, citrinin, and ochratoxin A on amino acid uptake and incorporation by cucumber. Can. J. Bot. 1972, 50, 2659-2664.

63. Damodaran, C.; Kathirvel-Pandian, S.; Seeni, S. Citrinin, a phytotoxin? Cell. Mol. Life Sci. 1975, 31, 1415-1417.

64. Betina, V. Mycotoxins: Chemical, Biological and Environmental Aspects; Elsevier: New York, NY, USA, 1989.

65. Maćias, M.; Ulloa, M.; Gamboa, A.; Mata, R. Phytotoxic compounds from the new coprophilous fungus Guanomyces polythrix. J. Nat. Prod. 2000, 63, 757-761.

66. Chagas, G.M.; Wambier Kluppel, M.L.; Campello, A.P.; Buchi, D.F.; Oliveira, M.B.M. Alterations induced by citrinin in cultured kidney cells. Cell Struct. Funct. 1994, 19, 103-108.

67. Chagas, G.M.; Oliveira, M.B.M.; Campello, A.P.; Kluppel, M.L.W. Mechanism of citrinin-induced dysfunction of mitochondria. IV. Effect on $\mathrm{Ca}^{2+}$ transport. Cell Biochem. Funct. 1995, 13, 53-59.

68. Chain, E.; Florey, H.W.; Jennings, M.A. An antibacterial substance produced by Penicillium claviforme. Brit. J. Exp. Pathol. 1942, 23, 202-205.

69. Birkinshaw, H.; Bracken, A.; Michael. S.E.; Raistrick, H. Patulin in the common cold. II. Biochemistry and chemistry. Lancet 1943, 245, 625-630.

70. Florey, H.W.; Jennings, M.A.; Philpot, F.J. Claviformin from Aspergillus giganteus Wehm. Nature (London) 1944, 153, 139. 
71. Singh, J. Patulin. In Antibiotics; Gottlieb, D., Shaw, P.D., Eds.; Springer Verlag: New York, NY, USA, 1967; pp. 621-630.

72. Lovett, J.; Peeler, J.T. Effect of $\mathrm{pH}$ on the thermal destruction kinetics of patulin in aqueous solution. J. Food Sci. 1973, 38, 1094-1095.

73. Moake, M.M.; Padilla-Zakour, O.I.; Worobo, R.W. Comprehensive review of patulin control methods in foods. Compr. Rev. Food Sci. F 2005, 4, 8-21

74. Gye, W.E. Patulin in the common cold. III. Preliminary trial in the common cold. Lancet 1943, $245,630-631$.

75. Hopkins J. The toxicological hazards of patulin. Food Cosmet. Toxicol. 1993, 31, 455-459.

76. Stansfeld, J.H.; Francis, A.E.; Stuart-Harris, C.H. Laboratory and clinical trials of patulin. Lancet 1944, 244, 370-372.

77. Sant'Ana, A.S.; Rosenthal, A.; Massaguer, P.R. The fate of patulin in apple juice processing: A review. Food Res. Int. 2008, 41, 441-453.

78. Steiman, R.; Seigle-Murandi, F.; Sage, L.; Krivobok, S. Production of patulin by Micromycetes. Mycopathologia 1989, 105, 129-133.

79. Welke, J.E.; Hoeltz, M.; Dottori, H.A.; Noll, I.B. Patulin accumulation in apples during storage by Penicillium expansum and Penicillium griseofulvum strains. Braz. J. Microbiol. 2011, 42, 172-180.

80. Umezawa, H.; Mizuhara. Y.; Uekane, K.; Hagihara, M. A crystalline antibacterial substance from Penicillium leucopus and four other strains of Penicillia, and Aspergillus clavatus, and its probable identity with patulin. Jpn. J. Med. 1947, 1, 97-100.

81. Frisvad, J.C.; Smedsgaard, J.; Larsen, T.O.; Samson, R.A. Mycotoxins, drugs and other extrolites produced by species in Penicillium subgenus Penicillium. Stud. Mycol. 2004, 49, 201-242.

82. Ciegler, A. Patulin. In Mycotoxins in Human and Animal Health; Rodricks, J.V., Hesseltine, C.W., Mehlman, M.A., Eds.; Pathotox Publishers Inc: Park Forest South, IL, USA, 1977; pp. 609-624.

83. Barta, J.; Mecir. R. Antibacterial activity of Penicillium divergens Bainier. Experienfia 1948, 4, 277-278.

84. Fang-Chao, X.; Chun-Lin, L.; Xiang-Zheng, Y.; Yi-Lun, C. Isolation of main patulin-producing strains from storage pears and their ITS sequences analysis and identification. Food Ferment. Ind. 2011, 37, 54-57.

85. Varga, J.; Due, M.; Frisvad, J.C.; Samson, R.A. Taxonomic revision of Aspergillus section Clavati based on molecular, morphological and physiological data. Stud. Mycol. 2007, 59, 89-106.

86. Jiménez, M.; Mateo, R.; Querol, A.; Huerta, T.; Hernández, E. Mycotoxins and mycotoxigenic moulds in nuts and sunflower seeds for human consumption. Mycopathologia 1991, 115, 121-127.

87. Jackson, L.; Dombrink-Kurtzman, M.A. Patulin. In Microbiology of Fruits and Vegetables; Sapers, G.M., Gorny, J.R., Yousef, A.E., Eds.; CRC Press: Boca Raton, FL, USA, 2006; pp. 281-311.

88. Samson, R.A.; Houbraken, J.; Varga, J.; Frisvad J.C. Polyphasic taxonomy of the heat resistant ascomycete genus Byssochlamysand its Paecilomycesanamorphs. Persoonia 2009, 22, 14-27. 
89. Rovira, R.; Ribera, F.; Sanchis, V.; Canela, R. Improvements in the quantitation of patulin in apple juice by high performance liquid chromatography. J. Agric. Food Chem. 1993, 41, 214-216.

90. Sanderson, P.G.; Spotts, R.A. Postharvest decay of winter pear and apple fruit caused by species of Penicillium. Phytopathology 1995, 85, 103-110.

91. Morales, H.; Marin, S.; Rovira, A.; Ramos, A.J.; Sanchis, V. Patulin accumulation in apples by Penicillium expansum during postharvest stages. Lett. Appl. Microbiol. 2007, 44, 30-35.

92. Sommer, N.F.; Buchanan, J.R.; Fortlage, R.J. Production of patulin by Penicillium expansum. Appl. Microbiol. 1974, 28, 589-593.

93. European Union. Commission Regulation No. 1425/2003 Amending Commission Regulation No.1881/2006 Setting Maximum Levels for Certain Contaminants in Foodstuffs; European Union: Brussels, Belgium, 2006.

94. Börner, H. The formation of antibiotic and antiphytotoxic compounds in soil and their possible use for the self-incompatibility of apples in the nursery. Mitt. Biol. Bundesanst. Land Forstwirt. Berlin-Dahlem 1963, 108, 27-29.

95. McCalla, T.M.; Guenzi, W.D.; Norstadt, F.A. Microbial studies of phytotoxic substances in the stubble-mulch system. Z. Allg. Mikrobiol. 1963, 3, 202-210.

96. Ellis, J.R.; McCalla, T.M. Effects of patulin and method of application on growth stages of wheat. Appl. Microbiol. 1973, 25, 562-566.

97. Liu, B.H.; Wu, T.S.; Yu, F.Y.; Su, C.C. Induction of oxidative stress response by the mycotoxin patulin in mammalian cells. Toxicol. Sci. 2007, 95, 340-347.

98. Polacco, J.C.; Sands, D.C. The mycotoxin patulin inhibits respiration of higher plant cells. Plant Sci. Lett. 1977, 9, 121-128.

99. Fliege, R.; Metzler, M. The mycotoxin patulin induces intra- and intermolecular protein cross links in vitro involving cysteine, lysine, and histidine side chains, and $\alpha$-amino groups. Chem. Biol. Interact. 1999, 123, 85-103.

100. Ashoor, S.H.; Chu, F.S. Inhibition of alcohol and lactic dehydrogenases by patulin and penicillic acid in vitro. Food Cosmet. Toxicol. 1973, 11, 617-624.

101. Ashoor, S.H.; Chu, F.S. Inhibition of muscle aldolase by penicillic acid and patulin in vitro. Food Cosmet. Toxicol. 1973, 11, 995-1000.

102. Alsberg, G.L.; Black, O.F. Contributions to the study of maize deterioration: Biochemical and toxicological investigations of Penicillium puberulum and P. stoloniferum. U.S. Dep. Agric. Bureau Plant Ind. Bull. 1913, 270, 1-47.

103. Oxford, A.E.; Raistrick, H. Studies in the biochemistry of micro-orgaisms. I- Erythritol, a metabolic product of Penicillium brevi-compactum Dierckx and P. cyclopium Westling. Biochem. J. 1935, 29, 1599.

104. Birkinshaw, J.H.; Oxford, A.E.; Raistrick, H. Studies in the biochemistry of microorganisms. XL VIII. Penicillic acid, a metabolite product of Penicillium puberulum Bainier and P. cyclopium Westling. Biochem. J. 1936, 30, 394-411.

105. Oxford, A.E.; Raistrick, H.; Smith, G. Anti-bacterial substances from moulds. Part II. Penicillic acid, a metabolic product of Penicillium puberulum Bainier and Penicillium cyclopium Westling. Chem. Ind. 1942, 10, 22-24. 
106. Bentley, R.; Keil, J.G. Tetronic acid biosynthesis in molds II. Formation of penicillic acid in Penicillium cyclopium. J. Biol. Chem. 1962, 237, 867-873.

107. Shaw, E. A synthesis of protoanemonin; the tautomerism of acetylacrylic acid and of penicillic acid. J. Am. Chem. Soc. 1946, 68, 2510-2513.

108. Macri, A.; Dancea, Z.; Baba, A.I. Mycotoxin Involvement in Oncogenesis: Bibliographical Investigations; Buletinul Universitii de stiinte Agricole si Medicina Veterinara Cluj Nopoca Seria Medicina Veterinara: Cluj-Nopoca, Romania, 2002; Volume 58, pp. 640-644.

109. He, J.; Wijeratne, E.M.K.; Bashyal, B.P.; Zhan, X.J.; Seliga, C.J.; Liu, M.X.; Pierson, E.E.; Pierson, L.S., III; van Etten, H.D.; Gunatilaka, A.A.L. Cytotoxic and other metabolites of Aspergillus inhibiting the rhizosphere of Sonoran desert plants. J. Nat. Prod. 2004, 67, 1985-1991.

110. Ezzat, S.M.; El-Sayed, A.E.; Abou El-Hawa, M.I.; Ismaiel, A.A. Morphological and ultrastructural studies for the biological action of penicillic acid on some bacterial species. Res. J. Microbiol. 2007, 2, 303-314.

111. Nonaka, K.; Chiba, T.; Suga, T.; Asami, Y.; Iwatsuki, M. Coculnol, a new penicillic acid produced by a coculture of Fusarium solani FKI-6853 and Talaromyces sp. FKA-65. J. Antibiot. 2015, doi:10.1038/ja.2015.15.

112. Ismaiel, A.A. Effect of Acidic Microbial Toxins on Morphology and Ultrastructure of Bacteria. Ph.D. Thesis, Zagazig University, Zagazig, Egypt, September 2007.

113. Bresler, G.; Brizzio, S.B.; Vaamonde, G. Mycotoxin-producing potential of fungi isolated from amaranth seeds in Argentina. Int. J. Food Microbiol. 1995, 25, 101-108.

114. Kang, S.W.; Park, C.H.; Hong, S.I.; Kim, S.W. Production of penicillic acid by Aspergillus sclerotiorum CGF. Biores. Technol. 2007, 98, 191-197.

115. SohYoung, O.; IllMin, C.; SuBong, P.; Seunghum, Y. Survey and control of the occurrence of mycotoxins from post harvest. I. Mycotoxins produced by Penicillium isolates from corn and wheat cereals. Korean J. Plant Pathol. 1998, 14, 700-704.

116. Gedek, P.; Bauer, J.; Schreiber, H. Mycotoxin production of silage deteriorating molds. Wien Tierarztl Monatsschr 1981, 68, 299-301.

117. Lund, F.; Frisvad, J.C. Chemotaxonomy of Penicillium aurantiogriseum and related species. Mycol. Res. 1994, 98, 481-492.

118. Hesseltine, C.W. Natural occurrence of mycotoxins in cereals. Mycopathol. Mycol. Appl. 1974, $53,141-153$.

119. Lindenfelser, L.A.; Ciegler, A. Penicillic acid production in submerged culture. Appl. Environ. Microbiol. 1977, 34, 553-556.

120. Andersen B. Consistent production of phenolic compounds by Penicillium brevicompactum for chemotaxonomic characterization. Antonie Leuwenhoek 1991, 60, 115-123.

121. Tuthill, D.E.; Frisvad, J.C. Eupenicillium bovifimosum, a new species from dry cow manure in Wyoming. Mycologia 2002, 94, 240-246.

122. Garza, S.; Canela, R.; Vinas, I.; Sanchis, V. Effects of potassium sorbate on growth and penicillic acid production by Aspergillus ochraceus and Penicillium aurantiogriseum. Zentralbl Mikrobiol. 1993, 148, 343-350.

123. Ciegler, A. Bioproduction of ochratoxin A and penicillic acid by members of the Aspergillus ochraceus group. Can. J. Microbiol. 1972, 18, 631-636. 
124. Namikoshi, M.; Negishi, R.; Nagai, H.; Dmitrnok, A.; Kobyahi, H. Three new chlorine containing antibiotics from a marine-derived fungus Aspergillus ostianus collected in Pohnpei. J. Antibiot. (Tokyo) 2003, 56, 755-761.

125. Bastin, R.; van Roey, G. Action of some antibiotics and inhibiting substances on cellular stretching. P. Pharm. Belg. 1954, 9, 112-127.

126. Reiss, J. Inhibitory action of the mycotoxins patulin and penicillic acid on urease. Food Cosmet. Toxicol. 1979, 17, 145-146.

127. Tashiro, F.; Hirai, K.; Ueno, Y. Inhibitory effects of carcinogenic mycotoxins on deoxyribonucleic acid-dependent ribonucleic acid polymerase and ribonuclease H. Appl. Environ. Microbiol. 1979, 38, 191-196.

128. Ciegler, A.; Mintzlaff, H.J.; Weisleder, D.; Leistner, L. Potential production and detoxification of penicillic acid in mold-fermented sausage (Salami). Appl. Microbiol. 1972, 24, 114-119.

129. Sassa, T.; Hayakari, S.; Ikeda, M.; Miura, Y. Plant growth inhibitors produced by fungi. I. Isolation and identification of penicillic acid and dihydropenicillic acid. Agr. Biol. Chem. 1971, $35,2130-2131$.

130. Martínez-Luis, S.; González, M.C.; Ulloa, M.; Mata, R. Phytotoxins from the fungus Malbranchea aurantiaca. Phytochemistry 2005, 66, 1012-1016.

131. Ahmad, A.; Eqbal, M.M. Effect of penicillic acid on some biochemical changes in germinating maize seeds. Geobios 2002, 29, 161-163.

132. Fondy, T.P.; Everse, J.; Driscou G.A.; Castillo, F.; Stolzenbach, F.E.; Kaplan, N.O. The comparative enzymology of lactic dehydrogenases. IV. Function of sulfhydryl groups in lactic dehyrogenases and the sequence around the essential group. J. Biol. Chem. 1965, 240, 4219-4234.

133. Ciegler, A.; Kurtzman, C.P. Penicillic acid production by blue-eye fungi on various agricultural commodities. Appl. Microbiol. 1970, 20, 761-764.

134. Kurtzman, C.P.; Ciegler, A. Mycotoxin from a blue-eye mold of corn. Appl. Microbiol. 1970, 20, 204-207.

135. Van Der Merwe, K.J.; Steyne, P.S.; Fourie, L.; Scott, D.B.; Theron, J.J. Ochratoxin A, a toxic metabolite produced by Aspergillus ochraceus. Nature 1965, 205, 1112-1113.

136. Horie, Y. Productivity of ochratoxin A of Aspergillus carbonarius in Aspergillus section Nigri. Nippon Kingakukai Kaiho 1995, 36, 73-76.

137. Abarca, M.L.; Bragulat, M.R.; Sastella, G.; Cabanes, F.J. Ochratoxin A production by strains of Aspergillus niger var. niger. Appl. Environ. Microbiol. 1994, 60, 2650-2652.

138. Ciegler, A.; Fennell, D.J.; Mintzlaff, H.J.; Leistner, L. Ochratoxin synthesis by Penicillium species. Naturwissenschaften 1972, 59, 365-366.

139. Gil-Serna, J.; González-Salgado, A.; González-Jaén, M.A.T.; Vázquez, C.; Patiño, B. ITS-based detection and quantification of Aspergillus ochraceus and Aspergillus westerdijkiae in grapes and green coffee beans by real-time quantitative PCR. Int. J. Food Microbiol. 2009, 131, 162-167.

140. Lund, F.; Frisvad, J.C. Penicillium verrucosum in wheat and barley indicates presence of ochratoxin A. J. Appl. Microbiol. 2003, 95, 1117-1123.

141. Bogs, C.; Battilani, P.; Geisen, R. Development of a molecular detection and differentiation system for ochratoxin A producing Penicillium species and its application to analyse the occurrence of Penicillium nordicum in cured meats. Int. J. Food Microbiol. 2006, 107, 39-47. 
142. Beardall, J.; Miller, J.D. Natural occurrence of mycotoxins other than aflatoxin in Africa, Asia and South America. Mycotox. Res. 1994, 10, 21-40.

143. Sweeney, M.J.; White, S.; Dobson, A.D.W. Mycotoxins in agriculture and food safety. Ir. J. Agr. Food Res. 2000, 39, 235-244.

144. Wang, Y.; Peng, X.; Xu, W.; Luo, Y.; Zhao, W. Transcript and protein profiling analysis of OTA-induced cell death reveals the regulation of the toxicity response process in Arabidopsis thaliana. J. Exp. Bot. 2011, 29, 1-17.

145. Peng, X.L.; Xu, W.T.; Wang, Y.; Huang, K.L.; Liang, Z.H.; Zhao, W.W.; Luo, Y.B. Mycotoxin ochratoxin A-induced cell death and changes in oxidative metabolism of Arabidopsis thaliana. Plant Cell Rep. 2010, 29, 153-161.

146. McLean, M. The phytotoxicity of selected mycotoxins on mature, germinating Zea mays embryos. Mycopathologia 1996, 132, 173-183.

147. Ringot, D.; Chango, A.; Schneider, Y.; Larondelle, Y. Toxicokinetics and toxicodynamics of ochratoxin A, an update. Chem. Biol. Interact. 2006, 159, 18-46.

148. Wang, Y.; Zhao, W.; Hao, J.; Xu, W.; Luo, Y.; Wu, W. Changes in biosynthesis and metabolism of glutathione upon ochratoxin A stress in Arabidopsis thaliana. Plant Physiol. Biochem. 2014, $79,10-18$.

149. Rosett, T.; Sankhala, R.H.; Stickings, C.E.; Taylor, M.E.U.; Thomas, R. Biochemistry of microorganisms. CIII. Metabolites of Alternaria tenuis auct: Culture filtrate products. Biochem. J. 1957, 67, 390-400.

150. Stickings, C.E. Studies in the biochemistry of micro-organisms. 106. Metabolites of Alternaria tenius auct: The structure of tenuazonic acid. Biochem. J. 1959, 72, 332-340.

151. Nolte, M.J.; Steyn, P.S.; Wessels, P.L. Structural investigations of 3-acylpyrrolidine-2,4-diones by nuclear magnetic resonance spectroscopy and X-ray crystallography. J. Chem. Soc. Perkin Trans. 1 1980, doi:10.1039/P19800001057.

152. Mikula, H.; Horkel, E.; Hans, P.; Hametner, C.; Fröhlich, J. Structure and tautomerism of tenuazonic acid-A synergetic computational and spectroscopic approach. J. Hazard. Mater. 2013, 250-251, 308-317.

153. Shigeura, H.T.; Gordon, C.N. The biological activity of tenuazonic acid. Biochemistry 1963, 2, 1132-1137.

154. Aver'yanov, A.A.; Lapikova, V.P.; Lebrun, M.H. Tenuazonic Acid, Toxin of Rice Blast Fungus, Induces Disease Resistance and Reactive Oxygen Production in Plants. Russ. J. Plant Pathol. 2007, 54, 749-754.

155. Kinoshita, T.; Renbutsu, Y.; Khan, I.D.; Kohmojo, K.; Nishimura, S. Distribution of tenuazonic acid production in the genus Alternaria and its pathological evaluation. Ann. Phytopathol. Soc. (Jpn.) 1972, 38, 397-404.

156. Umetsu, N.; Kaji, J.; Tamari, K. Investigation on the toxin production by several blast fungus strains and isolation of tenuazonic acid as a novel toxin. Agric. Biol. Chem. 1972, 36, 859-866.

157. Umetsu, N.; Kaji, J.; Aoyama, K.; Tamari, K. Toxins in blast diseased rice plants. Agri. Biol. Chem. 1974, 38, 1867-1874.

158. Davis, N.D.; Diener, U.L.; Morgan-Jones, G. Tenuazonic acid production Alternaria alternata and Alternaria tenuissima isolated from cotton. Appl. Environ. Microbiol. 1977, 34, 155-159. 
159. Steyn, P.S.; Rabie, C.J. Characterization of magnesium and calcium tenuazonate from Phoma sorghina. Phytochemistry 1976, 15, 1977-1979.

160. Janardhanan, K.K.; Husain, A. Phytotoxic activity of tenuazonic acid isolated from Alternaria alternata (Fr.) Keissler causing leaf blight of Datura innoxia Mill. and its effect on host metabolism. J. Phytopathol. 1984, 111, 305-311.

161. Lebrun, M.H.; Nicolas, L.; Boutar, M.; Gaudemer, F.; Ranomenjanahary, S.; Gaudemer, A. Relationships between the structure and the phytotoxicity of the fungal toxin tenuazonic acid. Phytochemistry 1988, 27, 77-84.

162. Carrasco, L.; Vazquez, D. Survey of inhibitors in different steps of protein synthesis by mammalian ribosomes. J. Antibiot. 1972, 25, 732-737.

163. Barbacid, M.; Vazquez, D. $\left({ }^{3} \mathrm{H}\right)$ anisomycin binding to eukaryotic ribosomes. J. Mol. Biol. 1974, 84, 603-623.

164. Barbacid, M.; Vazquez, D. Binding of [acetyl- ${ }^{14} \mathrm{C}$ ] trichodermin to the peptidyl transferase centre of eukaryotic ribosomes. Eur. J. Biochem. 1974, 44, 437-444.

165. Park, P. Effect of the host-specific toxin and other toxic metabolites by Alternaria kikuchiana on ultrastructure of leaf cells of Japanese pear. Ann. Phytopath. Soc. (Jpn.) 1977, 43, 15-25.

166. Binder, M.; Tamm, C.; Turner, W.B.; Minato, H. Nomenclature of a class of biologically active mould metabolites: The cytochalasins, phomins, and zygosporins. J. Chem. Soc. Perkin Trans. 1 1973, 11, 1146-1147.

167. Rothweiler, W.; Tamm, C. islation and structure of phomin. Expertientia 1966, 22, 750-752.

168. Rothweiler, W.; Tamm, C. Isolierung and struktur der Antibiotica phomin und 5-Dehydrophomin. Helv. Chim. Acta 1970, 53, 696-724.

169. Aldridge, D.C.; Armstrong, J.J.; Speake, R.N.; Turner, W.B. The structure of cytochalasins A and B. J. Chem. Soc. C 1967, doi:10.1039/J39670001667.

170. Cole, R.J.; Jarvis, B.B.; Schweikert, M.A. Handbook of Secondary Fungal Metabolites; Academic Press: San Diego, CA, USA, 2003; Chapters 14-20, Volume III, pp. 199-560.

171. Lindholm, C.; Norppa, H.; Hayashi, M.; Sorsa, M. Induction of micronuclei and anaphase aberrations by cytochalasin B in human lymphocyte cultures. Mutat. Res. 1991, 260, 369-375.

172. Fenech, M.; Morley, A.A. Measurement of micronuclei inlymphocytes. Mutat. Res. 1985, 147, 29-36.

173. Falck, G.; Catalan, J.; Norppa, H. Influence of culture time on the frequency and contents of human lymphocytes micronuclei with and without cytochalasin B. Mutat. Res. 1997, 392, 71-79.

174. Minissi, S.; Gustavino, B.; Degrassi, F.; Tanzarela, C.; Rizzoni, M. Effect of cytochalasin B on the induction of chromosome missegregation by colchicine at low concentrations in human lymphocytes. Mutagenesis 1999, 14, 43-49.

175. Chao, J.I.; Liu, H.F. The blockage of survivin and securin expression increases the cytochalasin B-induced cell death and growth inhibition in human cancer cells. Mol. Pharmacol. 2006, 69, $154-164$.

176. Ismaiel, A.A. Morphogenesis and Physiological Activity of Some Microorganisms as Affected by the Mycotoxin Cytochalasin. Master Thesis, Zagazig University, Zagazig, Egypt, March 2005. 
177. Scott, P.M.; Harwig, J.; Chen, Y.K.; Kennedy, B.P.C. Cytochalasins A and B from strains of Phoma exigua var. exigua and formation of cytochalasin B in potato gangrene. J. Gen. Microbiol. 1975, 87, 177-180.

178. Capasso, R.; Evidente, A.; Ritieni, A.; Radazzo, G.; Vurro, M.; Bottalico, A. Ascochalasin, a new cytochalasin from Ascochyta heteromorpha. J. Nat. Prod. 1988, 51, 567-571.

179. Capio, E.R.; Tate, M.E.; Wallwork, H. Phytotoxic metabolites from Drechslera wirreganensis and D. campanulata. Aust. Plant Pathol. 2004, 33, 23-28.

180. Carlier, M.F.; Ciquet, P.; Pantalont, D.; Korn, E.D. Interaction of cytochalasins D with actin filaments in the presence of ADP and ATP. J. Biol. Chem. 1986, 261, 2041-2050.

181. Zholkevich, V.N.; Chugunova, T.W. Interaction between cytoskeletal proteins, biomediators and phytohormones in the regulation of water transport in plants. Doklady Biol. Sci. 1995, 341, 163-165.

182. Seagull, R.W. Cytoskeletal stability affects fiber initiation. Int. J. Plant Sci. 1998, 159, 590-598.

183. Decognet, V.; Citharel, J. Production of cytochalasins by Phoma exigua var. linicola. Asp. Appl. Biol. 1991, 28, 107-110.

184. Huang, R.F.; Wang, X.C. Effects of cytochalasin B on stomatal movement of Vicia faba. Acta Phytophysiol. Sin. 1996, 22, 404-408.

185. Teng, X.Y.; Zhuang, L.X. The role of actin tip growth of pollen tube. Acta Phytophysiol. Sin. 1997, 23, 239-244.

186. Kadota, A.; Wada, M. Cytoskeletal aspects of nuclear migration during tip growth in the fern Adiantum protonemal cell. Protoplasma 1995, 188, 170-179.

187. Stitt, A.W.; Fairweather, I.; Johnston, C.F. Fasciola hepatica: Disruption of spermatogenesis by the microfilament inhibitor cytochalasin B. Parasitol. Res. 1991, 77, 123-128.

188. Tamagnini, R.P.; Romano, B; Frenguelli, G.; Bisogni, A.M. Effect of cytochalasin B on germinating seeds of Psium sativum L. respiration, ultrastructure of cotyledon cells, storage substances, acid phosphatase activity. J. Botanico Italiano 1983, 117, 227-236.

189. Abdrakhimova, I.R.; Kholkhlova, L.P. Modifiers of cytoskeleton proteins and regulation of electron transport pathways of plant respiration. Doklady Biol. Sci. 2000, 372, 273-275.

190. Thomas, D. des S.; Lager, N.M.; Manavathu, E.K. Cytochalasin B: Effect on root morphogenesis in Allium cepa. Can. J. Bot. 1973, 51, 2269-2273.

191. Eleftheriou, E.P.; Palevitz, B.A. The effect of cytochalasin D on preprophase band organization in root tip cells of Allium. J. Cell Sci. 1992, 103, 989-998.

192. Behboodi, B.S.; Samadi, L. Mitotic apparatus movement and cell wall pattering in root apical meristem of Allium cepa. Pakistan J. Bot. 2002, 34, 405-410.

193. Siugimoto, M.; Toyada, K.; Ichinose, Y.; Yamada, T.; Shiraishi, T. Cytochalasin A inhibits the binding of phenylalanine ammonia lyase mRNA to ribosomes during induction of phytoalexin in pea seedlings. Plant Cell Physiol. 2000, 411, 234-238.

194. Quader, H.; Liebe, S. Actin filament-independent formation of tubular endoplasmic reticulum in onion epidermis cell. J. Plant Physiol. 1995, 145, 71-77.

195. Gravis, C.; Newcomb, W.; Simmonds, D.H. Rearrangement of the actin filament and microtubule cytoskeleton during induction of microspore embryogenesis in Brassica napus L.C.V. topas. Protoplasma 2001, 213, 194-202. 
196. Traas, J.A.; Burgain, S.; Dumas, De vaul, R. The organization of the cytoskeleton during meiosis in egg plant (Solanum melongena (L.)): Microtubules and F-actin are both necessary for coordinated meiotic division. J. Cell Sci. 1989, 92, 541-550.

197. Sawai, K.; Okuno, T.; Fujioka, H.; Furuyo, M. The relation between the phytotoxicity of cytochalasin E and its molecular structure. Ann. Phytopathol. Soc. Jpn. 1983, 49, 262-265.

198. Kanematsu, S.; Hayashi, T.; Kudo, A. Isolation of Rosellinia necatrix mutants with impaired cytochalasin E production and its pothogenicity. Ann. Phytopathol. Soc. Jpn. 1997, 63, 425-431.

199. Zonno, M.C.; Vurro, M. Effect of fungal toxins on germination of Striga hermonthica seeds. Weed Res. Oxf. 1999, 39, 15-20.

200. Kshirsagar, A.; Reid, A.J.; Maccol, S.M.; Saunders, V.A.; Whalky, A.J.S.; Evans, E.H. The effect of fungal metabolites on leaves as detected by chlorophyll fluorescence. New Phytol. 2001, $151,451-457$.

201. Evidente, A.; Andolfi, A.; Vurro, M.; Zonno, M.C.; Matto, A. Cytochalasins Z1, Z2 and Z3, three 24-Oxa(14)cytochalasins produced by Pyrenophora semeniperda. Phytochemistry 2002, $60,45-53$.

202. Masi, M.; Meyer, S.; Cimmino, A.; Andolfi, A.; Evidente, A. Pyrenophoric Acid, a Phytotoxic sesquiterpenoid Penta-2,4-dienoic acid produced by a potential Mycoherbicide, Pyrenophora semeniperda. J. Nat. Prod. 2014, 77, 925-930.

203. Masi, M.; Evidente, A.; Meyer, S.; Nicholson, J.; Munoz, A. Effect of strain and cultural conditions on the production of cytochalasin B by the potential mycoherbicide Pyrenophora semeniperda (Pleosporaceae, Pleosporales). Biocontrol Sci. Technol. 2014, 24, 53-64.

204. Nukina, M. The blast disease fungi and their metabolic products. J. Pestic. Sci. 1999, 24, 239-298.

205. Fujii, Y.; Tani, H.; Ichinoe, M.; Nakajima, H. Zygosporin D and Two New Cytochalasins Produced by the fungus Metarrhizium anisopliae. J. Nat. Prod. 2000, 63, 132-135.

206. Cole, R.J.; Cox, R.H. The trichothecenes. In Handbook of Toxic Fungal Metabolites; Academic Press: Toronto, ON, Canada, 1981; pp. 152-263.

207. Wilkins, K.; Nielsen, K.; Din, S. Patterns of volatile metabolites and nonvolatile trichothecenes produced by isolates of Stachybotrys, Fusarium, Trichoderma, Trichothecium and Memnoniella. Environ. Sci. Pollut. Res. 2003, 10, 162-166.

208. Trapp, S.C.; Hohn, T.M.; McCormick, S.; Jarvis, B.B. Characterization of the gene cluster for biosynthesis of macrocyclic trichothecenes in Myrothecium roridum. Mol. Gen. Genet. 1998, $257,421-432$.

209. Jarvis, B.B.; Mazzola, E.P. Macrocyclic and other novel trichothecenes: Their structure, synthesis, and biological significance. Acc. Chem. Res. 1982, 15, 388-395.

210. Freeman, G.G.; Morrison, R.I. Trichothecin: An antifungal metabolic product of Trichothecium roseum Link. Nature 1948, 162, 30.

211. Brian, P.W.; Dawkins, A.W.; Grove, J.F.; Hemming, H.G.; Lowe, D.; Norris, G.L.F. Phytotoxic compounds produced by Fusarium equiseti. J. Exp. Bot. 1961, 12, 1-12.

212. Tatsuno, T.M.; Saito, M.; Enomoto, M.; Tsunoda, H. Nivalenol, a toxic principle of Fusarium nivale. Chem. Pharm. Bull. 1968, 16, 2519-2520. 
213. Bamburg, J.R.; Riggs, N.V.; Strong, F.M. The structures of toxins from two strains of Fusarium tricinctum. Tetrahedron 1968, 24, 3329.

214. Marasus, W.F.O.; Nelson, P.E.; Toussoun, T.A. Toxigenic Fusarium Species; Pennsylvania State University Press: University Park, PA, USA, 1984.

215. Vesonder, R.F.; Hesseltine, C.W. Vomitoxin: Natural occurrence on cereal grains and significance as a refusal and emetic factor to swine. Process Biochem. 1980, 44, 12-14.

216. Savard, M.E.; Blackwell, B.A.; Greenhalgh, R. An ${ }^{1} \mathrm{H}$ nuclear magnetic resonance study of derivatives of 3-hydroxy-12,13-epoxytrichothec-9-enes. Can. J. Chem. 1987, 65, 2254-2262.

217. Savard, M.E.; Blackwell, B.A. Spectral characteristics of secondary metabolites from Fusarium Fungi. In Mycotoxins in Grain; Miller, J.D., Trenholm, H.L., Eds.; Eagen Press: St. Paul, MI, USA, 1994; pp. 59-228.

218. Jarvis, B.B.; Mazzocchi, D.B.; Ammon, H.L.; Mazzola, E.P.; Flippen-Anderson, J.L.; Gilardi, R.D.; George, C.F. Conformational effects in trichothecenes: Structures of 15-hydroxy C4 and C8 ketones. J. Org. Chem. 1990, 55, 3660-3662.

219. Shank, R.A.; Foroud, N.A.; hazendonk, P.; Eudes, F.; Blackwell, A. Current and future experimental strategies for structural analysis of trichothecene mycotoxins-A prospectus. Toxins 2011, 3, 1518-1553.

220. Greenhalgh, R.; Blackwell, B.A.; Savard, M.E. The NMR spectra of trichothecenes and related fungal metabolites. Tetrahedron 1989, 45, 2373-2383.

221. Schollenberger, M.; Drochner, W.; Müller, H.-M. Fusarium toxins of the scirpentriol subgroup: A review. Mycopathologia 2007, 164, 101-118.

222. Ueno, Y. Toxicological features of T-2 toxin and related trichothecenes. Toxicol. Sci. 1984, 4, S124-S132.

223. Jarvis, B.B.; Midiwo, J.O.; Bean, G.A.; Aboul-Nasr, M.B.; Barnos, C.S. The mystery of trichothecene antibiotics in Baccharis species. J. Nat. Prod. 1988, 51, 736-744.

224. Bertoni, M.D.; Romero, N.; Reddy, P.V.; White, J.F., Jr. A hypocrealean epibiont on meristems of Baccharis coridifolia. Mycologia 1997, 89, 375-382.

225. Ueno, Y. Trichothecenes: Chemical, Biological, and Toxicological Aspects; Elsevier: Amsterdam, The Nerthlands, 1983.

226. Cutler, H.G. Trichothecenes and their role in the expression of plant disease. In Biotechnology for Crop Protection; Hedin, P.A., Menn, J.J., Hollingworth, R.M., Eds.; Maple Press: York, PA, USA, 1988; pp. 50-72.

227. Cheeke, P.R. Natural Toxicant in Feeds, Forages, and Poisonous Plants; Interstate Publishers Inc.: Danville, IL, USA, 1998.

228. CAST (Council for Agriculture Science and Technology). Mycotoxins Risks in Plant, Animal, and Human Systems; CAST: Ames, IA, USA, 2003.

229. Harris, L.J.; Desjardins, A.E.; Plattner, R.D.; Nicholson, P.; Butler, G.; Young, J.C.; Weston, G.; Proctor, R.H.; Holn, T.M. Possible role of trichothecenes mycotoxins in virulence of Fusarium graminearum on maize. Plant Dis. 1999, 83, 954-960.

230. Wang, H.; Hwang, S.F.; Eudes, F.; Chang, K.F.; Howard, R.J.; Turnbull, G.D.; Trichothecenes and aggressiveness of Fusarium graminaearum causing seeding blight and root rot in cereals. Plant Pathol. 2006, 55, 224-230. 
231. Abbas, H.K.; Johnson, B.B.; Shier, W.T.; Tak, H.; Jarvis, B.B.; Boyette, C.D. Phytotoxicity and mammalian cytotoxicity of macrocyclic trichothecene mycotocins from Myrothecium verrucaria. Phytochemistry 2002, 59, 309-313.

232. Zonno, M.C.; Vurro, M. Inhibition of germination of Orobanche ramose seeds by Fusarium toxins. Phytoparasitica 2002, 30, 519-524.

233. Abbas, H.K.; Duke, S.O.; Merrill, A.H. Jr.; Wang, E.; Shier, W.T. Phytotoxicity of australifungin, AAL-toxins and fumonisin B 1 to Lemna pausicostata. Phytochemistry 1998, 47, 1509-1514.

234. Morin, L.; Gianotti, A.F.; Lauren, D.R. Trichothecene production and pathogenicity of Fusarium tumidum, a candidate bioherbicides for gorse and broom in New Zealand. Mycol. Res. 2000, 104, 993-999.

235. Tanaka, T.; Abbas, H.K.; Duke, S.O. Structure-dependent phytotoxicity of fumonisins, and related compound in a duckweed bioassay. Phytochemistry 1993, 33, 779-785.

236. Vesonder, R.F.; Golinski. P. Metabolites of Fusarium. In Fusarium Mycotoxins, Taxonomy and Pathogenicity; Chelkowski, J., Ed.; Elsevier Publishers: Amsterdam, The Nertanlands, 1989; pp. 1-39.

237. Atanassov, Z.; Nakamura, C.; Mori, N.; Kaneda, C.; Kato, H.; Jin, Y.-Z.; Yoshizawa, T.; Murai, K. Mycotoxin production and pathogenicity of Fusarium species and wheat resistance to Fusarium head blight. Can. J. Bot. 1994, 72, 161-167.

238. Snijders, C.H.A.; Krechting, C.F. Inhibition of deoxynivalenol translocation and fungal colonization in Fusarium head blight resistant wheat. Can. J. Bot. 1992, 70, 1570-1576.

239. Wakulinski, W. Phytotoxicity of the secondary metabolites of fungi causing wheat head fusariosis (head blight). Acta Physiol. Plant 1989, 11, 301-306.

240. Rocha, L.G.; Almeida, J.R.G.S.; Macedo, R.O.; Barbosa-Filho, J.M. A review of natural products with antileishmanial activity. Phytomedicine 2005, 12, 514-535.

241. Shimada, T.; Otani, M. Effects of Fusarium mycotoxins on the growth of shoots and roots at germination in some Japanese wheat cultivars. Cereal Res. Commun. 1990, 18, 229-232.

242. Cossette, F.; Miller, J.D. Phytotoxic effect of deoxynivalenol and gibberella ear rot resistance of corn. Nat. Toxins 1995, 3, 383-388.

243. Bottalico, A.; Leario, P.; Visconti, A. Some experimental data on the phytotoxicity of mycotoxins. Phytopath. Medit. 1980, 19, 196-198.

244. Bandurska, H.; Chelkowski, J.; Wisniewska, H. Free proline accumulation in wheat seedlings influenced by Fusarium culmorum infection and the pathogen metabolite deoxynivaienol. Acta Physiol. Plant 1994, 16, 111-116.

245. Menke-Milczarek, I.; Zimny, J. Phytotoxicity of deoxynivalenol to wheat calli. Mycotox. Res. 1991, 7, 146-149.

246. Packa, D. Cytogenetic changes in plant cells as influenced by mycotoxins. Mycotox. Res. 1991, 7, 150-155.

247. Rahman, M.F.; Bilgrami, K.S.; Masood, A. Cytotoxic effects of DON and T-2 toxin on plant cells. Mycopathologia 1993, 124, 95-97. 
248. Miller, J.D. Effects of Fusarium graminearum metabolites on wheat cells. In Phytotoxins and Plant Pathogenesis; Granti, A., Durbin, R.D., Ballio, A., Eds.; NATO ASI Series, Springer Netherlands: Heidelberg, Germany, 1989; pp. 449-452.

249. Snijders, C.H.A. Breeding for resistance to Fusarium in wheat and maize. In Mycotoxins in Grain. Compounds other than Aflatoxin; Miller, J.D., Trenholm, H.L., Eds.; Eagan Press: St. Paul, MN, USA, 1994; pp. 37-58.

250. Scott, P.M. The natural occurrence of trichothecenes. In Trichothecene Mycotoxins: Pathophysiologic Effects; Beasley, V.R., Ed.; CRC Press: Boca Raton, FL, USA, 1989; pp. 1-26.

251. Miller, J.D. Epidemiology of Fusarium ear diseases in cereals. In Myeotoxins in Grain. Compounds Other than Aflatoxin; Miller, J.D., Trenholm, H.L., Eds.; Eagan Press: St. Paul, MN, USA, 1994; pp. 19-36.

252. Thompson, W.L.; Wannemacher, R.W. Structure-function relationship of 12,13-epoxytrichothecene mycotoxins in cell culture: Comparison to whole animal lethality. Toxicon 1986, 24, 985-994.

253. Terse, P.S.; Madhyastha, M.S.; Zurovac, O.; Stringfellow, D.; Marquardt, R.R.; Kemppainen, B.W. Comparison of in vitro and in vivo biological activity of mycotoxins. Toxicon 1993, 31, 913-919.

254. Chang, N.T.; Xue, Y.L. Effect of T-2 toxin on wheat leaf protoplasts. Chin. Sci. Bull. 1990, 35, 431-434.

255. Vesonder, R.F.; Labeda, D.P.; Peterson, R.E. Phytotoxie activity of selected water-soluble metabolites of Fusarium against Lemna minor L. (Duckweed). Mycopathologia 1992, 118, $185-189$.

256. Cole, R.J.; Kirksey, J.W.; Cutler, H.G.; Doubnik, B.L.; Peckham, J.C. Toxin from Fusarium moniliforme: Effects on plants and animals. Science 1973, 179, 1324-1326.

257. Burmeister, H.R.; Ciegler, A.; Vesonder, R.F. Moniliformin, a metabolite of Fusarium moniliforme NRRL 6322: Purification and toxicity. Appl. Environ. Microbiol. 1979, 37, 11-13.

258. Burmeister, H.R.; Grove, M.D. Kwolek, W.F. Moniliformin and butenolide: Effect on mice of high-level, long-term oral intake. Appl. Environ. Microbiol. 1980, 40, 1142-1144.

259. Springer, J.P.; Clardy, J.; Cole, R.J.; Kirksey, J.W.; Hill, R.K.; Carlson, R.M.; Isidor, J.L. Structure and synthesis of moniliformin, a novel cyclobutane microbial toxin. J. Am. Chem. Soc. 1974, 96, 2267-2268.

260. Steyn, M.; Thiel, P.G.; van Schalkwyk, G.C. Isolation and purification of moniliformin. J. Assoc. Off. Anal. Chem. 1978, 61, 578-580.

261. Booth, C. The Genus Fusarium; Commonwealth Mycological Institute: Kew, UK, 1971.

262. Rable, C.J.; Lubben, A.; Louw, A.I.; Rathbone, E.B.; Steyn, P.S.; Vleggaar, R. Moniliformin, a mycotoxin from Fusarium fusarioides. J. Agric. Food Chem. 1978, 26, 375-379.

263. Marasas, W.F.O.; Leistner, L.; Hofmann, G.; Eckardt, C. Occurrence of toxigenic strains of Fusarium in maize and barley in Germany. European J. Appl. Microbiol. Biotechnol. 1979, 7 , 289-305.

264. Burka, L.T.; Doran, J.; Wilson, B.J. Enzyme inhibition and the toxic action of moniliformin and other vinylogous $\alpha$-ketoacids. Biochem. Pharmacol. 1982, 31, 79-84.

265. Chen, L.Y.; Tian, X.L.; Yang, B. A study on the inhibition of rat myocardium glutathione peroxidase and glutathione reductase by moniliformin. Mycopathologia 1990, 110, 119-124. 
266. Pirrung, M.C.; Nauhaus, S.K.; Singh, B. Cofactor-directed, time-dependent inhibition of thiamine enzymes by the fungal toxin moniliformin. J. Org. Chem. 1996, 61, 2592-2593.

267. Deruiter, J.; Jacyno, J.M.; Cutler, H.G.; Davis, R.A. Studies on aldose reductase inhibitors from fungi. II. Moniliformin and small ring analogues. J. Enzyme Inhib. 1993, 7, 249-256.

268. Reams, R.; Thacker, H.L.; Novilla, M.; Laska, D.; Horn, J.; Harrington, D.; Greenlee, W.; Vesonder, R. Development of an L6 myoblast in vitro model of moniliformin toxicosis. Mycopathologia 1996, 133, 105-114.

269. Kriek, N.P.; Marasas, W.F.; Steyn, P.S.; van Rensburg, S.J.; Steyn, M. Toxicity of a moniliformin-producing strain of Fusarium moniliforme var. subglutinans isolated from maize. Food Cosmet. Toxicol. 1977, 15, 579-587.

270. Uhlig, S.; Jestoi, M.; Parikka, P. Fusarium avenaceum-The north European situation. Int. J. Food Microbiol. 2007, 119, 17-24.

271. Thiel, P.G.; Marasas, W.E.O.; Sydenham, E.W.; Shephard, G.S.; Gelderblom, W.C.A.; Nieuwenhuis, J.J. Survey of fumonisin production by Fusarium species. Appl. Environ. Microbiol. 1991, 57, 1089-1093.

272. Rheeder, J.P.; Marasas, W.E.O.; Vismer, H.E. Production of fumonisin analogs by Fusarium species. Appl. Environ. Microbiol. 2002, 68, 2101-2105.

273. Gelderblom, W.C.A.; Jaskiewicz, K.; Marasas. W.F.; Thiel, P.G.; Horak, R.M.; Vleggaar, R.; Kreik, N.P.J. Fumonisins-novel mycotoxins with cancer-promoting activity produced by Fusarium moniliforme. Appl. Environ. Microbiol. 1988, 54, 1806-1811.

274. Kellerman, T.S.; Marasas, W.F.O.; Thiel, P.G.; Gelderblom, W.C.A.; Cawood, M.; Coetser, J.A.W. Leukoencepahalomalacia in two horses induced by oral dosing of fumonisin B1, Ondersterpoort. J. Vet. Res. 1990, 57, 319-324.

275. Harrison, L.R.; Colvin, B.M.; Greene, J.T.; Newman, L.E.; Cole, J.R. Pulmonary edema and hydrothorax in swine produced by fumonisin B1, a toxic metabolite of Fusarium moniliforme. J. Vet. Diagn. Investig. 1990, 2, 217-221.

276. Rheeder, J.P.; Marasas, W.F.O.; Thiel, P.G.; Sydenham, E.W.; Shephard, G.S.; van Schalkwyk, D.J. Fusarium moniliforme and fumonisins in corn in relation to human esophageal cancer in Transkei. Phytopathology 1992, 82, 353-357.

277. Yoshizawa, T.; Yamashita, A.; Luo, Y. Fumonisin occurrence in corn from high- and low-risk areas for human oesophageal cancer in China. Appl. Enivron. Toxicol. 1994, 60, 1626-1629.

278. Abbas, H.K.; Boyette, C.D.; Hoagland, R.E.; Vesonder, R.E. Bioherbicidal potential of Fusarium moniliforme and its phytotoxin, fumonisin B1. Weed Sci. 1991, 139, 673-677.

279. Danielsen, S.; Jensen, D.E. Relationships between seed germination, fumonisin content, and Fusarium verticillioides infection in selected maize samples from different regions of Costa Rica. Plant Pathol. 1998, 47, 609-614.

280. Lamprecht, S.C.; Marasas, W.E.O.; Alberts, J.F.; Cawood, M.E.; Gelderblom, W.C.A.; Shephard, G.S. Phytotoxicity of fumonisins and TA-toxin to corn and tomato. Phytopathology 1994, 84, 383-391.

281. Abbas, H.K.; Boyette, C.D. Phytotoxicity of fumonisin B1 on weed and crop species. Weed Technol. 1992, 6, 548-552. 
282. Doehlert, D.C.; Knutson, C.A.; Vesonder, R.E. Phytotoxic effects of fumonisin B1 on maize seedling growth. Mycopathologia 1994, 127, 117-121.

283. Abbas, H.K.; Ocamb, C.M. First report of production of fumonisin B1 by Fusarium polyphialidicum collected from seeds of Pinus strobus. Plant Dis. 1995, 79, 642.

284. Jackowiak,H.; Packa, D.; Wiwart M.; Perkowski, J.; Busko, M.; Borusiewicz, A. Scanning electron microscopy of mature wheat kernels infected with Fusarium culmorum. J. Appl. Genet. 2002, 43, 167-176.

285. Pekkarinen, A.I.; Mannonen, L.; Jones, B.L.; Niku-Paavola, M.L. Production of proteases by Fusarium species grown on barley grains and in media containing cereal proteins. J. Cereal Sci. 2000, 31, 253-261.

286. Janardhan, A.; Subramanyam, D.; Praveen, A.; Reddi, M.; Narasimha G. Aflatoxin impacts on germinating seeds. Ann. Biol. Res. 2011, 2, 180-188.

287. Van Asch, M.A.J. Studies on the Resistance of Wheat and Maize to Fungal Pathogenesis. Ph.D. Thesis, University of Natal, Pietermaritzburg, South Africa, 1990.

288. Abbas, H.K.; Gelderblom, W.C.A.; Cawood, M.E.; Shier, W.T. Biological activities of fumonisins, mycotoxins from Fusarium moniliforme, in jimsonweed (Datura stramonium L.) and mammalian cell cultures. Toxicon 1993, 31, 345-353.

289. Abbas, H.K.; Duke, S.O.; Tanaka, T. Phytotoxicity of fumonisins and related compounds. J. Toxicol. Toxin Rev. 1993, 12, 225-251.

290. Krasnoff, S.B.; Sommers, C.H.; Moon, Y.-S.; Donzelli, B.G.G.; Vandenberg, J.D.; Churchill, A.C.L. Production of mutagenic metabolites by Metarhizium anisopliae. J. Agric. Food Chem. 2006, 54, 7083-7088.

291. Wiebe, L.A.; Bjeldanes, L.F. Fusarin C, a mutagen from Fusarium moniliforme grown on corn. J. Food Sci. 1981, 46, 1424-1426.

292. Gelderblom, W.C.A.; Marasas, W.F.O.; Steyn, P.S.; Thiel, P.G.; Van Der Merwe, K.J.; Van Rooyen, P.H. Structure elucidation of fusarin C, a mutagen produced by Fusarium moniliforme. J. Chem. Soc. Chem. Commun. 1984, 7, 122-124.

293. Savard, M.E.; Miller, D.J. Characterization of fusarin F, a new fusarin from Fusarium moniliforme. J. Nat. Prod. 1992, 55, 64-70.

294. Kleigrewe, K.; Aydin, F.; Hogrefe, K.; Piecuch, P.; Bergander, K.; Würthwein, E. Structure elucidation of new fusarins revealing insights in the rearrangement mechanisms of the Fusarium mycotoxin fusarin C. J. Agric. Food Chem. 2012, 60, 5497-5505.

295. Bacon, C.W.; Porter, J.K.; Norred, W.P.; Leslie, J.F. Production of fusaric acid by Fusarium species. Appl. Environ. Microbiol. 1996, 62, 4039-4043.

296. Sieber, C.M.K.; von Bargen, K.W.; Studt, L.; Niehaus, E.-M.; Espino, J.J. Deciphering the cryptic genome: Genome-wide analyses of the rice pathogen Fusarium fujikuroi reveal complex regulation of secondary metabolism and novel metabolites. PLoS Pathol. 2013, 9, e1003475.

297. Brown, D.W.; Butchko, R.A.E.; Busman, M.; Proctor, R.H. Identification of gene clusters associated with fusaric acid, fusarin, and perithecial pigment production in Fusarium verticillioides. Fungal Genet. Biol. 2012, 49, 521-532. 
298. Abbas, H.K.; Mirocha, C.J.; Kommedahl, T.; Vesonder, R.F.; Golinski, P. Production of trichothecene and non-trichothecene mycotoxins by Fusarium species isolated from maize in Minnesota. Mycopathologia 1989, 108, 55-58.

299. Bacon, C.W.; Marijanovic, D.R.; Norred, W.P.; Hinton, D.M. Production of fusarin C on cereal and soybean by Fusarium moniliforme. Appl. Environ. Microbiol. 1989, 55, 2745-2748.

300. Tseng T. Mycotoxins produced by Fusarium spp. of Taiwan. Bot. Bull. Acad. Sin. 1993, 34, 261-269.

301. Gäumann E. Fusaric acid as a wilt toxin. Phytopathology 1957, 47, 342-357.

302. Stipanovic, R.D.; Wheeler, M.H.; Puckhaber, L.S.; Liu, J.; Bell, A.A.; Williams, H.J. Nuclear magnetic resonance (NMR) studies on the biosynthesis of fusaric acid from Fusarium oxysporum f. sp. vasinfectum. J. Agric. Food Chem. 2011, 59, 5351-5356.

303. Shilina, S.G.; Bekker, Z.E.; Goshaev, M.G. Isolation and comparative characterization of vivotoxin from wilt-infected cotton plants and of fusaric acid. Ekologo-Fiziologlcheskle Metody Bor'be Fuzarioznym Viltom Khlop 1973, 2, 219-230.

304. D'Alton, A.; Etherton, B. Effects of fusaric acid on tomato root hair membrane potentials and ATP levels. Plant Physiol. 1984, 74, 39-42.

305. Marré, M.T.; Vergani, P.; Albergoni, F.G. Relationship between fusaric acid uptake and its binding to cell structures by leaves of Egeria densa and its toxic effects on membrane permeability and respiration. Physiol. Mol. Plant Pathol. 1993, 42, 141-157.

306. Bouizgarne, B.; El-Maarouf-Bouteau, H.; Frankart, C.; Reboutier, D.; Madiona, K.; Pennarun, A.M. Early physiological responses of Arabidopsis thaliana cells to fusaric acid: Toxic and signalling effects. New Phytol. 2006, 169, 209-218.

307. Dong, X.; Ling, N.; Wang, M.; Shen, Q.; Guo, S. Fusaric acid is a crucial factor in the disturbance of leaf water imbalance in Fusarium-infected banana plants. Plant Physiol. Biochem. 2012, 60, 171-179.

308. Cheeke, P.R.; Shull, L.R. Mycotoxins. In Natural Toxicants in Feeds and Poisonous Plants; AVI Publishing Company Inc.: Westport, CT, USA, 1985; pp. 393-477.

309. Mirocha, C.J.; Christensen, C.M. Oestrogenic mycotoxins synthesized by Fusarium. In Mycotoxins; Purchase, I.F.H., Ed.; Elsevier: Amesterdam, The Nerthlands, 1974; pp. 129-148.

310. McNutt, S.H.; Purwin, P.; Murray, C. Vulvovaginitis in swine. J. Am. Vet. Med. Assoc. 1928, 73, 484-492.

311. Graham, R.; Tunnicliff, E.A.; McCullock E.C. Spoiled feed shown to be the cause of pig trouble. Agric. Exp. Sta. Annu. Rep. 1928, 41, 144-145.

312. Koen, J.S.; Smith, H.C. An unusual case of genital involvement in swine associated with eating moldy corn. Vet. Med. 1945, 40, 131-133.

313. Christensen, C.M.; Nelson, G.H.; Mirocha, C.J. Effect on the white rat uterus of a toxic substance isolated from Fusarium. Appl. Microbiol. 1965, 13, 653-659.

314. Pullar, M.E.; Lerew, W.M. Vulvovaginitis of swine. Aust. Vet. J. 1937, 13, 28-31.

315. McErlean, B.A. Vulvovaginitis of swine. Vet. Rec. 1952, 64, 539-540.

316. Stob, M.; Baldwin, R.S.; Tuite, J.; Andrews, F.N.; Gillette, K.G. Isolation of an anabolic, uterotrophic compound from corn infected with Gibberella zeae. Nature 1962, 196, 13-18. 
317. Urry, W.H.; Wehrmeister, H.L.; Hodge, E.B.; Hidy, P.H. The structure of zearalenone. Tetrahedron Lett. 1966, 27, 3109-3114.

318. Mirocha, C.J.; Christensen, C.M.; Nelson, G.H. Estrogenic metabolite produced by Fusarium graminiearuin in stored corn. Appl. Microbiol. 1967, 15, 497-503.

319. Codex Committee on Food Additives and Contaminants (CCFAC). Posting Date. Joint FAO/WHO Expert Committee on Food Additives: Position Paper on Zearalenone; Publication CCFAC 00/19; Codex Alimentarius Commission: Rome, Italy, 2000.

320. Zill, G.; Engelhardt, G.; Wohner, B.; Wallnoefer, P.R. The fate of Fusarium mycotoxin zearalenone in maize cell suspension cultures. Mycotox. Res. 1990, 6, 31-40.

(C) 2015 by the authors; licensee MDPI, Basel, Switzerland. This article is an open access article distributed under the terms and conditions of the Creative Commons Attribution license (http://creativecommons.org/licenses/by/4.0/). 